\title{
STEREOTOMY AND THE MEDITERRANEAN: NOTES TOWARD AN ARCHITECTURAL HISTORY*
}

\author{
SARA GALLETTI \\ DUKE UNIVERSITY
}

\begin{abstract}
Stereotomy, the art of cutting stones into particular shapes for the construction of vaulted structures, is an ancient art that has been practiced over a wide chronological and geographical span, from Hellenistic Greece to contemporary Apulia and across the Mediterranean Basin. Yet the history of ancient and medieval stereotomy is little understood, and nineteenthcentury theories about the art's Syrian origins, its introduction into Europe via France and the crusaders, and the intrinsic Frenchness of medieval stereotomy are still largely accepted. In this essay, I question these theories with the help of a work-in-progress database and database-driven maps that consolidate evidence of stereotomic practice from the third century $\mathrm{BCE}$ through the eleventh century $\mathrm{CE}$ and across the Mediterranean region. I argue that the history of stereotomy is far more complex than what historians have assumed so far and that, for the most part, it has yet to be written.
\end{abstract}

\section{Key Words}

Stereotomy, stone vaulting, applied geometry, history of construction techniques.

\footnotetext{
I am very grateful to John Jeffries Martin and Jörn Karhausen for reading drafts of this essay and providing important suggestions. I am also indebted to the faculty and students of the Centre Chastel (INHA, Paris), where I presented an early version of this essay in April 2016, for helping me clarify aspects of my research. Philippe Cabrit, a maitre tailleur of the Compagnons du devoir de France, helped me immensely by generously sharing his knowledge of the practice of stereotomy. This essay is dedicated to Maitre Cabrit as a token of my gratitude.
}

Mediterranea. International journal on the transfer of knowledge 2 (2017), pp.73-120 ISSN: 2445-2378

(c) The author(s). Published by UCOPress. Cordoba University Press. All rights reserved. 
Stereotomy is the art of cutting stones into particular shapes for the construction of vaulted structures. Stereotomic vaults are distinguished from the broader family of stone vaults by the size, shape, and assembling technique of their components (voussoirs). An example of a stereotomic vault covers the lower portico in the courtyard of the Palace of Charles V in Granada (Fig. 1), while examples of the broader category of stone vaults cover the nave of the Church of Saint Séverin in Paris (Fig. 2). In Granada, the large (compared to the overall dimensions of the vault) voussoirs were individually cut to fit each other precisely and then dry-assembled like the pieces of a three-dimensional puzzle. In Saint Séverin, instead, the vaults' severies (the compartments formed between the ribs) were built using smaller stones of standard shape and size, and, like bricks, they are held together by mortar that fills the joints. While the curvature of the Granada vault results from the accurate shaping of its voussoirs, the curvature of the Saint Séverin vaults results from the shaping of its mortar fillings.

Stereotomy is best known for a variety of acrobatic masterpieces produced in early modern France and Spain, such as the composite vault in the Town Hall of Arles or the floating staircase in the Lonja de Mar of Barcelona (Fig. 3). It is also known through a substantial body of theory that started with the treatises of architects such as Philibert de L'Orme (1514-70) and Alonso de Vandelvira (15441625), and, via two centuries of elaborations, gave birth to descriptive geometry, the branch of mathematics concerned with the two-dimensional representation of three-dimensional objects. ${ }^{1}$ However, the art is neither early modern nor European; it has been practiced over a wide chronological span, from Hellenistic Greece to contemporary Apulia, and across a broad geographical range, centered

\footnotetext{
Philibert de L'Orme, Premier tome de l'architecture, Paris: Morel, 1567 and Alonso de Vandelvira and Geneviève Barbé-Coquelin de Lisle (ed.), El tratado de arquitectura de Alonso de Vandelvira [Libro de trazas de cortes de piedras, ca. 1585], Madrid: Confederación Española de Cajas de Ahorros, 1977. Fundamental early modern theories of stereotomy include: Ginés Martínez de Aranda and Antonio Bonet Correa (ed.), Cerramientos y trazas de montea [ca. 1600], Madrid: Servicio Histórico Militar, Comisión de Estudios Históricos de Obras Públicas y Urbanismo, 1986; Gérard Desargues, Brouillon projet d'exemple d'une manière universelle du S.G.D.L. touchant la praticque du trait à preuve pour la coupe des pierres en l'architecture, Paris, 1640; Mathurin Jousse, Le secret d'architecture découvrant fidèlement les traits géométriques, couppes, et derobemens nécessaires dans les bastiments enrichi d'un grand nombre de figures, adioustées sur châque discours pour l'explication d'iceux, La Flèche: George Griveau, 1642; Amédée-François Frézier, La théorie et la pratique de la coupe des pierres et des bois, ou traité de stéréotomie à l'usage de l'architecture, Strasbourg: Dousseker, 1737-39; and Benito Bails, Elementos de matemática, Madrid: Joachin Ibarra, 1779-90. The theory of descriptive geometry was formulated in Gaspard Monge, Géométrie descriptive: leçons données aux Écoles normales l'an 3 de la République, Paris: Gabay, 1798. On the origins of descriptive geometry and its relation to stereotomy, see Joël Sakarovitch, Épures d'architecture: de la coupe des pierres à la géométrie descriptive, XVI ${ }^{e}-X I X^{e}$ siècles, Basel: Birkhäuser, 1998.
} 
on the Mediterranean Basin but reaching far beyond-from Cairo to Gloucester, from Yerevan to Braga. Stereotomy's wide dissemination is not matched in its frequency; the art has remained marginal in all the cultures in which it has been practiced across time and space. Extant examples are a very small percentage of extant stone vaults, no matter what chronological or geographical context is being observed, and there is no reason to believe that stereotomic vaults were destroyed at a higher rate than other stonemasonries. Their infrequency is unsurprising, for stereotomy not only requires a sophisticated understanding of curved solids and a perfect mastery of stonecutting techniques, requirements that make a stereotomic vault difficult to conceive and to produce, but it also defies one of construction's fundamental tenets: to provide effective solutions to structural problems. Inefficient for all involved in its making-the designers, the stonecutters, and oftentimes the stones themselves-the art of stereotomy is superfluous from the standpoint of structure: no stereotomic vault is per se necessary, and all pre-modern and early modern stereotomic vaults could have been built using different techniques or materials-and, without exception, doing so would have been in the interest of labor, time, and money. ${ }^{2}$ Indeed, stereotomy is best described as a virtuoso art. It is the construction equivalent of scientists' legendary bumblebee, 'which cannot possibly fly' but does. ${ }^{3}$ Stereotomy testifies to human playfulness and to the pleasures associated with intellectual puzzles and wondrous objects, as well as to the values attributed to high-skilled workmanship, quality of construction, and the aesthetic significance of the seemingly least ornamental aspects of architecture.

Stereotomy has attracted the attention of architectural historians, especially after the groundbreaking work of Jean-Marie Pérouse de Montclos, whose L'architecture à la française (1982) focuses on France but has inspired the study of stereotomy in other countries, Spain and Italy in particular. ${ }^{4}$ This growing body

2 3D-modeling software and computer-aided cutting machines have made contemporary stereotomy a far more efficient practice and one with a high structural, spatial, and aesthetic potential in contemporary architecture, as shown by the research conducted by Claudio D'Amato Guerrieri, Francesco Defilippis, and Giuseppe Fallacara at the School of Architecture and Civil Engineering of the Polytechnic of Bari, Italy. See in particular Richard Etlin, Giuseppe Fallacara, and Luc Tamborero (eds.), Plaited Stereotomy: Stone Vaults for the Modern World, Rome: Aracne, 2008; Giuseppe Fallacara et al. (eds.), Stereotomy: Stone Architecture and New Research, Paris: Presses des Ponts, 2012.

3 On the legend of the bumblebee that cannot fly and its debunking, see Douglas L. Altshuler et al., 'Short-amplitude high-frequency wing strokes determine the aerodynamics of honeybee flight', PNAS 102, 50 (2005), pp. 18213-18218. The quote is from Antoine Magnan, Le vol des insects, Paris: Hermann, 1934, p. 8.

4 Jean-Marie Pérouse de Montclos, L'architecture à la française: du milieu du XV à la fin du XVIII siècle, Paris: Picard, 1982. On Spain, see in particular José Carlos Palacios, Trazas y cortes de cantería en el Renacimiento español, Madrid: Instituto Juan de Herrera, 1990; José Calvo López, Cerramientos y trazas de montea de Ginés Martínez de Aranda, Ph.D. diss., Universidad Politécnica de 
of literature focuses almost exclusively on early modern Europe, however, and theories about the art's origins and its modes of dissemination across the ancient and medieval Mediterranean have gone largely unquestioned. In particular, the notion that stereotomy was imported into Western Europe from Syria by the crusaders-a theory first advanced by Eugène-Emmanuel Viollet-le-Duc in the nineteenth century-is still largely accepted, despite Fernand Braudel's work on the Mediterranean and post-Braudelian studies on the sea and its networks. ${ }^{5}$ Similarly, Viollet-le-Duc's assumption that, once imported into France, stereotomy developed along an uninterrupted line of progress through the Middle Ages has never been put to the test; also untested is his construal of stereotomy as a quintessentially French art, and, indeed, both notions inform the work of Pérouse de Montclos and his followers. ${ }^{6}$ Last but not least, uses of the term stereotomy and definitions of what constitutes a stereotomic work vary

Cartagena, 1999; Arturo Zaragozá Catalán, El arte de corte de piedras en la arquitectura valenciana del cuatrocientos: un estado de la cuestión, Valencia: Real Academia de Bellas Artes de San Carlos de Valencia, 2008; and Juan Carlos Navarro Fajardo (ed.), Bóvedas valencianas: arquitecturas ideales, reales y virtuales en época medieval y moderna, Valencia: Editorial Universitat Politècnica de València, 2014. On Italy, see especially Marco Rosario Nobile (ed.), Matteo Carnilivari, Pere Compte: 1506-2006: due maestri del gotico nel Mediterraneo, Palermo: Caracol, 2006; Maria Mercedes Bares, Il Castello Maniace di Siracusa: stereotomia e tecniche costruttive nell'architettura del Mediterraneo, Siracusa: Emanuele Romeo, 2011; Giuseppe Antista and Maria Mercedes Bares, Le scale in pietra a vista nel Mediterraneo, Palermo: Caracol, 2013; Marco Rosario Nobile (ed.), La stereotomia in Sicilia e nel Mediterraneo: guida al Museo di Palazzo La Rocca a Ragusa Ibla, Palermo: Caracol, 2013; and Id., 'Rinascimento alla francese: Gabriele Licciardo, architettura e costruzione nel Salento della metà del Cinquecento', Artigrama 30 (2015), pp. 193-219.

5 Eugène-Emmanuel Viollet-le-Duc, Dictionnaire raisonné de l'architecture française $d u \mathrm{XI}^{e}$ au XVI siècle, Paris: B. Bance, 1854-68, vol. 9, pp. 197-198. While stimulating essays can be found in Jaynie Anderson (ed.), Crossing Cultures: Conflict, Migration and Convergence, Carlton: Miegunyah Press, 2009 and Heather E. Grossman and Alicia Walker (eds.), Mechanisms of exchange: transmission in medieval art and architecture of the Mediterranean, ca. 1000-1500, Leiden: Brill, 2013, there is no art historical equivalent to seminal studies of the Mediterranean like Fernand Braudel, La Méditerranée et le monde méditerranéen à l'époque de Philippe II, Paris: Colin, 1949; Peregrine Horden and Nicholas Purcell, The Corrupting Sea: A Study of Mediterranean History, Oxford: Blackwell, 2000; and David Abulafia, The Great Sea: A Human History of the Mediterranean, New York: Oxford University Press, 2011.

6 The 2013 revised edition of Pérouse de Montclos's Architecture à la française (first published in 1982), integrates none of the literature published in the past three decades on medieval and early modern stereotomy outside of France, including in Armenia, Egypt, Italy, and Spain. The book therefore largely overstates the dominance of French practice in the field of stereotomy. Similarly, Philippe Potiés analyses of early modern stereotomy rely on the misleading notion that French medieval practitioners had developed a full mastery of the art: Philippe Potié, Philibert de l'Orme, figures de la pensée constructive, Marseille: Parenthèses, 1996 and Id., 'Le tracé d'épure, des carnet médiévaux aux traités de stéréotomie', in Jean-Philippe Garric, Valérie Nègre, and Alice Thomine-Berrada (eds.), La construction savante: les avatars de la littérature technique, Paris: Picard, 2008, pp. 149-160. 
Stereotomy and the Mediterranean: Notes Toward an Architectural History

significantly across the literature, which has the effect of destabilizing the boundaries of stereotomy as a discipline, thus contributing to the blurring of its history.

In this essay, I first propose an operative definition of stereotomy, and then I question the received historiography and suggest a revision of the current theory on the art's origins. Finally, I point to new, potentially more productive ways of approaching its ancient and medieval history. On the basis of preliminary but substantial data on stereotomic practice in the ancient and medieval Mediterranean, I argue that the history of stereotomy is far more complex than what historians have assumed so far and that, for the most part, it has yet to be written.

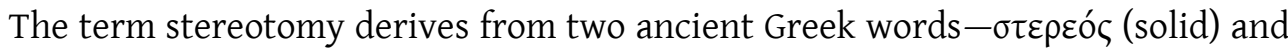

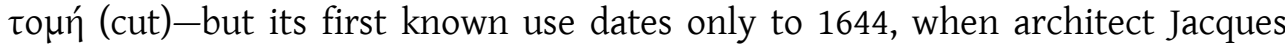
Curabelle defined it as the 'section of solids applied to stonecutting'.? Before Curabelle, French theoreticians used art du trait (art of drawing, from the Latin tractus, drawing), pratique du trait (practice of drawing), and trait de maçonnerie (masonry drawing) to identify the series of geometric constructions necessary to produce a stereotomic work. ${ }^{8}$ Similarly, in Spain, the expressions in use included arte de la traza (art of drawing) and arte de cantería (art of stonecutting). ${ }^{9}$

While the term stereotomy has been used since the seventeenth century to cover both the speculative (planning and drawing) and the practical (tracing and cutting) components of the art, today members of the Compagnonnage-a French professional association of workers in the building industry-often prefer to speak, instead, of taille/coupe de pierre (stonecutting), which they see as emphasizing the practical aspects of the centuries-long art they proudly continue. ${ }^{10}$ Their rationale is that, while stereotomy can be construed as a purely abstract discipline within the subfield of solid geometry (as in Desargues, Brouillon projet, 1640), the expression taille/coupe de pierre implies the execution in stone of the complex-shape voussoirs defined in the preparatory drawings for a vault's construction. For the same reason, academic studies often favor the terms

\footnotetext{
Jacques Curabelle, Examen des œuvres du Sr. Desargues, Paris: Henault, 1644, p. 3.

8 See, among others, L'Orme, Premier tome; Jean Chéreau, Traité d'architecture [1567-74], Biblioteka Publiczna, Gdanzk, ms. 2280; Jacques Gentillâtre, Livre d'architecture [ca. 1615-25], Bibliothèque nationale de France, ms. fond français 14727; and Jousse, Le secret d'architecture.

9 See, for example, Vandelvira, El tratado de arquitectura.

10 The publication that deals with stereotomy in the Encyclopédie des métiers edited by the Association ouvrière des Compagnons du devoir de France, is titled La maçonnerie et la taille de pierre, Paris: Librairie du compagnonnage, 1991-2007. The same terminology is employed in other modern professional manuals, such as Guy Jouberton, Tracés et coupes des pierres, Dourdan: Vial, 2007.
} 
stonecutting, taille/coupe de pierre, and cantería over stereotomy. ${ }^{11}$ However, outside of the professional ranks, whose codified and contextual uses provide specific meaning, neither 'stonecutting' nor its French and Spanish equivalents point specifically to vault construction, let alone the type of vault construction that de L'Orme, Vandelvira, and Curabelle wrote about. In fact, the frequent use of stereotomy and stonecutting as interchangeable terms in modern literature has introduced a slippage in meaning such that 'stereotomy' is often extended to structures whose execution requires no stereotomic knowledge-rib vaults, for instance, as well as barrel vaults and flat vaults. ${ }^{12}$ Beyond the confines of historical studies, the term has been so broadly applied that it may point to any form of ashlar masonry, including of the simplest kind (e.g. the flat, rectangular faces of the blocks that compose a straight wall), or even refer to solid, heavy, and continuous structural systems that rely on compressive strength in opposition to lightweight and/or skeletal systems. ${ }^{13}$

Recently, Claudio D'Amato, Giuseppe Fallacara, and Francesco Defilippis have proposed definitions of stereotomy based on 'invariant parameters' (prefigurative, technical-geometric, and static) and on execution criteria (the precision of cutting, the dry assembling, and the bareness of the intrados) that have helped frame the subject at hand. ${ }^{14}$ Indeed, all stereotomic vaults respond to these criteria: their creators subdivide the vaults' continuums into their components, the voussoirs (prefigurative invariant); they define the geometry of each voussoir (technical-geometric invariant) in order to accurately shape them

11 See, for instance, Sakarovitch, Épures d'architecture; Guillermo Herráez Cubino, El léxico de los tratados de cortes de cantería españoles del siglo XVI, Ph.D. diss., Universidad de Salamanca, 2007; and Juan Roldán Martín (ed.), El arte de la piedra: teoría y práctica de la cantería, Madrid: CEU Ediciones, 2009.

12 See, among others, Pérouse de Montclos, L'architecture à la française, rev. $2^{\text {nd }}$ ed., pp. 139-142 and 161-166 and Sergio Luis Sanabria, 'From Gothic to Renaissance Stereotomy: The Design Methods of Philibert de l'Orme and Alonso de Vandelvira', Technology and Culture 30, 2 (1989), pp. 266299 , both of which cover rib vaults, flat vaults, and barrel vaults in discussions of stereotomy.

13 See, for instance, Andrea Deplazes and Christoph Wieser, 'Solid and Filigree Construction', in Andrea Deplazes (ed.), Constructing Architecture: Materials, Processes, Structures, Basel: Birkhäuser, 2005 , p. 13, where stereotomy is used to mean 'solid construction' as opposed to 'filigree construction'. More examples are found in Francesco Bergamo and Gabriella Liva, Stereotomia: dalla pietra al digitale, Venice: Cafoscarini, 2010, pp. 43-45. These broad uses of the term stereotomy find their origin in the writings of Gottfried Semper, for instance in Gottfried Semper and Harry Francis Mallgrave (ed.), Style in the Technical and Tectonic Arts, or, Practical Aesthetics, Los Angeles: Getty Research Institute, 2004, p. 725.

14 Claudio D'Amato and Giuseppe Fallacara, 'Tradizione e innovazione nella progettazione/ costruzione dell'architettura: ruolo del 'modello' e attualità della stereotomia', in Id. (eds.), L'art de la stéréotomie/L'arte della stereotomia: Les compagnons du devoir et les merveilles de la construction en pierre/I compagnons du devoir e le meraviglie della costruzione in pietra, Paris: Librairie du compagnonnage, 2005, p. 54; Francesco Defilippis, Architettura e stereotomia: caratteri dell'architettura in pietra da taglio in area mediterranea, Bari: Poliba, 2010, pp. 45-48. 
before mounting (precision of cutting); they ensure the vaults' mechanical equilibrium (static invariant) in the absence of mortar (dry assembling); and they avoid plastering or painting the vaults' surfaces, so that viewers can appreciate the precision of execution of their joint lines as well as the patterns they form (bareness of the intrados). Yet none of these criteria address the geometric complexity that is at the core of the art's virtuosity, as they do not filter out the simple geometries that are of no concern to a stereotomist. After all, geometric complexity is central not only in distinguishing stereotomic vaults, but in defining them. Stereotomy's foundational theoretical texts focus on vaults of complex geometry (e.g. vaults featuring double curvatures and conics, such as domes and trumpet vaults, Fig. 4). Furthermore, the art has been consistently associated with geometric ingenuity and prowess. In de L'Orme's words: 'With the help of geometry, practitioners will learn how to cut the spherical and pyramidal solids in a variety of unusual manners and, thanks to the same skills and inventions, they will find ways to cut all sorts of stones in order to produce all sorts of vaults'. ${ }^{15}$

In order to redefine stereotomy both as a technical term and as a field of investigation, it is helpful to revisit the concerns of its early modern theoreticians. It was not stone vaulting in general that intrigued de L'Orme, Vandelvira, and their peers, but the type of stone vaulting that could not be executed solely on the basis of plans and elevations or sections-the traditional instruments of architectural representation. In other words, they were interested in vaults featuring joint lines that lie neither on the vertical or horizontal plane and whose plans, elevation, and sections, therefore, provide only shortened, skewed, or incomplete views of their voussoirs' sides. Examples would include the above-mentioned domes and trumpet vaults, as well as groin vaults, annular and helical vaults, skew arches, arrière voussures, and a variety of compositegeometry vaults (e.g. those that often support floating staircases). For instance, the joint lines of a trumpet vault lie on an inclined conic surface, so their lengths are shortened in both the plan and section of the vault (Fig. 5). A stonecutter, though, needs the true lengths of each of the joint lines in order to proceed with the shaping of the vault's voussoirs. To solve this problem, stereotomists use a field-specific type of drawing-de L'Orme's traits and Vandelvira's trazas-that materialize, on paper or stone, the geometric constructions that allow the developing (flattening) of the vault's conic surface, thus revealing the true lengths of its joint lines (Fig. 6). Most stonemasonries, including a number of vaults, fall out of the category here described and out of the concerns of stereotomists. The plan and elevation of a straight ashlar wall, for instance, contain all the information necessary to shape the stone blocks that compose it,

15 L'Orme, Premier tome, f. $128^{\mathrm{r}}$, my emphasis. 
with no need for further geometric constructions. The true dimensions and true shapes of the voussoirs that compose an arch, too, are provided by its plan and elevation, and the same is true of the ribs of a rib vault, which can be considered separately as single arches. Similarly, the plans and elevations of barrel vaults and flat vaults, which, from the point of view of geometry, are horizontal extrusions of arches and straight arches, provide all the information necessary to shape their voussoirs. None of these stonemasonries require the use of traits/trazas, and for precisely this reason none of them received much (if any) attention from de L'Orme, Vandelvira, and their followers. Including them in discussions of stereotomy hinders rather than it helps define the contours of the discipline. In order to reflect its practitioners' and theoreticians' concerns, therefore, I propose to define stereotomy as a practice and field of study that deals with vaulted structures that fit the above-mentioned criteria identified by D'Amato, Fallacara, and Defilippis, and whose geometries are complex enough that plans, elevations, and sections are not sufficient to provide all the information necessary to proceed with the cutting of their voussoirs.

The commonly accepted theory about the origins of stereotomy-first advanced by Eugène-Emmanuel Viollet-le-Duc-is that the art was born in ancient Greece and that, like other ancient construction techniques, it disappeared from the toolkit of Western craftsmen and was unknown in medieval Europe until the twelfth century, when the first crusaders imported it from Syria into France. ${ }^{16}$ According to Viollet-le-Duc, in Syria the crusaders found 'schools [of stereotomy]'-an expression that most likely refers to extant buildings featuring stereotomic vaults, such as the Roman Theatre in Shahba, the Audience Hall of alMundhir in Resafa, and the early Christian churches of Qalb Lozeh and of Saint Simeon Stylites (Fig. 7)-where they learned skills that they 'put to good use' once back home. ${ }^{17}$ Indeed, they would seem to have done so immediately, for the same author identifies the earliest example of medieval European stereotomy in the nave and narthex of the Abbey Church at Vézelay (ca. 1120-40, Fig. 8).

Viollet-le-Duc's theory-which identifies France as the cradle of medieval stereotomy-has thus far been challenged only by Sergio Sanabria and Pérouse de Montclos. Sanabria believes that stereotomy conquered Western Europe via Islam and Spain, not via the crusaders and France. For proof he cites the tenth-century rib domes in the maqsurah of Córdoba's Cathedral (Fig. 9a).${ }^{18}$ Pérouse de Montclos

\footnotetext{
Viollet-le-Duc, Dictionnaire raisonné, vol. 9, pp. 197-198.

Ibid., p. 198.

18 Sanabria, 'From Gothic to Renaissance Stereotomy', p. 267. Without offering an explanation, Sanabria discusses the ribs of the tenth-century domes of the maqsurah, which are covered in plaster and paint, as if the stonework was bare, as is the case for the thirteenth-century dome of the Villaviciosa Chapel (fig. 9b).
} 
believes that ancient and early Christian models from the eastern fringes of the Roman and Byzantine empires were too scarce and isolated to be significant for the development of medieval European stereotomy. He attributes its emergence in twelfth-century France to the presence of relevant Gallo-Roman models in the regions of Languedoc-Roussillon and Bouches-du-Rhône, in particular the Amphitheater and the Temple of Diana in Nimes, the Arles Amphitheater, and the Pont du Gard. ${ }^{19}$ He proceeds to trace a history of stereotomy as a distinctively French specialty-from Gallo-Roman times through the Middle Ages and to the early modern masterworks, in practice and theory, by de L'Orme, François and Jules Hardouin-Mansart, Robert de Cotte, and Frézier, among others. According to Pérouse de Montclos, all western stereotomy derives, directly or indirectly, from the same Languedoc region that produced the afore-mentioned GalloRoman monuments and what he calls the Romanesque 'archetypes' of later vaults, such as the annular vault of the Montmajour Abbey, the trumpet vault of the Church of Saint-Pierre in Nant, and the Vis Saint Gilles, the helical barrel vault covering the spiral staircase of the homonymous Abbey (Fig. 10). ${ }^{20}$

The competing theories of Viollet-le-Duc, Sanabria, and Pérouse de Montclos all invite a number of objections. For example, we might question the idea that stereotomy was imported into Western Europe in a linear fashion from a single point of origin by means of specific events, like the travels of the crusaders, or specific buildings, like the Córdoba Cathedral. It is not that such events and buildings lacked the potential to be agents of cultural transfer, but rather that such a theory disregards the presence of stereotomic works in places other than Syria and the abundance of types of exchange-materialized in the mobility of artists, objects, and knowledge-across the broader geography of the ancient and medieval Mediterranean. We might also question the hypothesis that the practice of stereotomy developed in Western Europe in a continuum from the twelfth to the sixteenth century; the number of known stereotomic vaults dating from the mid-thirteenth century through the mid-fifteenth century is simply too small to support it. Finally, it seems reasonable to question assumptions about the Frenchness of medieval and early modern stereotomy proffered by Viollet-le-Duc and Pérouse de Montclos since they are contradicted by the frequency and variety of stereotomic vaults built outside of France during the same time period.

The arguments I present in this essay are grounded in a work-in-progress database and database-driven maps of stereotomic vaults built in the

19 Pérouse de Montclos, L'architecture à la française, rev. $2^{\text {nd }}$ ed., pp. 181-182.

20 The traditional thirteenth-century date for the Vis Saint Gilles is uncertain, and the chronology of the building suggests that the staircase may have been executed at a later date, perhaps in the late fifteenth or early sixteenth century, see Pérouse de Montclos, L'architecture à la française, rev. $2^{\text {nd }}$ ed., pp. 143-144. 
Mediterranean region from antiquity through the fifteenth century (follow links to online Maps 1 and 2). ${ }^{21}$ This database consolidates information from a variety of printed and online sources, and it includes vaulted structures that fit the invariant parameters, execution criteria, and complex-geometry requirements described above. ${ }^{22}$ Excluded, therefore, are rib vaults, flat vaults, straight barrel vaults, cloister vaults, polygonal domes, and all other vault types whose voussoirs shapes are provided by plans and elevations or sections. ${ }^{23}$ The Google maps available to the reader here belong to the current beta-version of the database; once the database design is finalized, these maps will be replaced by ArcGIS maps that will provide readers with full navigation and data-retrieval control, including customization based on searches for vault types, locations, dates, and authors.

This collection is by no means an attempt to establish a comprehensive list of stereotomic vaults; it is an attempt, rather, to show that stereotomy has been practiced across a much wider chronological and geographical span than has thus far been recognized. Also, because stereotomy has been little studied outside of France and Spain, the data is inevitably biased, albeit unintentionally so. It should therefore be interpreted carefully and, in most cases, conservatively. For

21 The database and maps are part of the Mapping Stereotomy project directed by Sara Galletti and Kristin Huffman Lanzoni at Duke University's Wired Lab, http://www.dukewired.org/projects/ mapping-stereotomy/.

22 Sources include, but are not limited to: Christel Kessler, The Carved Masonry Domes of Mediaeval Cairo, Cairo: American University in Cairo Press, 1976; Palacios, Trazas y cortes de cantería; Calvo López, Cerramientos y trazas de montea; Patrick Donabédian, L'âge d'or de l'architecture arménienne: $V I I^{e}$ siècle, Marseille: Parenthèses, 2008; Zaragozá Catalán, El arte de corte de piedras; Fallacara et al., Stereotomy; Antista and Bares, Le scale in pietra a vista nel Mediterraneo; Pérouse de Montclos, L'architecture à la française, rev. $2^{\text {nd }}$ ed.; Nobile, La stereotomia in Sicilia e nel Mediterraneo; Navarro Fajardo, Bóvedas valencianas; California State University, Fresno, Index of Armenian Architecture, http://www.fresnostate.edu/artshum/armenianstudies/resources/indexarmenianarchite cture.html; Fundación Santa María La Real, Rómanico digital, http://www.romanicodigital.com; Institut du monde arabe, Qantara: Mediterranean Heritage, http://www.qantara-med.org; Nicolas Janberg, Structurae: International Database for Civil and Structural Engineering, https://structurae.net; Massachusetts Institute of Technology and Aga Khan Trust for Culture, ArchNet, http://archnet.org; Princeton University, Index of Christian Art: Romanesque Data base, https://ica.princeton.edu/romanesque/main.php; and Università degli Studi di Palermo, Cosmed: dalla stereotomia ai criteri antisismici: crocevia di sperimentazioni progettuali. Sicilia e Mediterraneo (XII-XVIII secolo), http://www.cosmedweb.org/immagini.php.

23 Unlike groin vaults, cloister vaults were usually built with no enchevêtrement of the voussoirs that belong to adjoining vault-panels (such enchevêtrement is essential for the stability of groin vaults, but superfluous for that of cloister vaults) in antiquity and through the Middle Ages. The voussoirs that compose cloister vaults with no enchevetrement can be obtained directly from the plan and section of the vault. The same applies to polygonal domes, which are also excluded from the data here. Among floating staircases, only those that are supported by complexgeometry vaults or composite vaults are included in the database. 
Stereotomy and the Mediterranean: Notes Toward an Architectural History

instance, because the only currently available catalogue of stereotomic vaults is Pérouse de Montclos's and deals exclusively with post-1450 France, we have fully relevant positive data (i.e. the occurrence and frequency of vaults) and negative data (i.e. the absence or rarity of vaults) only for French vaults dating from 1450 to $1500 .{ }^{24}$ For other areas and time periods, we must keep in mind that negative data may result from a lack of literature rather than a lack of vaults.

For the sake of clarity, I have used modern maps and modern names for sites, regions, and states. Each marker on the maps corresponds to a single building, no matter how many vaults or how many types of vaults it contains. The marker's color indicates the number of vault types (not number of vaults): yellow indicates one vault type; orange, two types; and red, three or more types. I highlight the number of vault types rather than the overall number of vaults featured in each building because the former is a better indicator of the stereotomic abilities of the designers and builders; it is more challenging to realize $n$ stereotomic vaults of different types than to produce $n$ iterations of the same type. The markers' shape indicates the availability of visual documentation: a diamond-shaped marker indicates that photographs (or sometimes drawings) of the vaults are available; a round marker indicates that, for the time being, they are not. ${ }^{25} \mathrm{An}$ asterisk indicates that the vault(s) or the building they belonged to have been substantially damaged or destroyed. The century indicated in each marker refers to the specific vault(s) listed underneath, not to the buildings they belong to.

Viollet-le-Duc's and Sanabria's theories about the Syrian origins of stereotomy and its development in medieval Europe rest on two assumptions: first, that Syria was the epicenter of stereotomy in the Eastern Mediterranean and, second, that stereotomy was not present in the Latin West before the Córdoba Caliphate and the crusades. Built evidence disproves both.

Paleochristian Syria was certainly fertile ground for stereotomy, as testified by a number of second- to sixth-century vaults documented in the region (Fig. 11 and link to online Map 1). Yet stereotomic vaults have been identified as far back as the third and second century BCE in Delphi and Pergamon, and between the first and the eleventh century CE, in modern Libya, Lebanon, Jordan, Turkey, Armenia, Israel, Azerbaijan, and Egypt (Fig. 12 and and link to online Map 1). Over the same period of time, these regions of the Eastern Mediterranean and the Middle East were connected by powerful networks of cultural and material exchange, fostered, at the large scale, by the power and economic structures of

24 Jean-Marie Pérouse de Montclos, 'Voûtes construites en France entre le milieu du XV ${ }^{\text {e }}$ siècle et la fin du XVIII', in Id., L'architecture à la française, rev. $2^{\text {nd }}$ ed., pp. 284-316.

25 The photographs linked to the maps are all licensed for non-commercial use under Creative Commons. Credits to their authors are listed separately at the end of the photo credits section of this essay. 
successive empires, and at the medium and small scale, by local linguistic, commercial, and migratory patterns. These networks make it impossible to establish with any degree of certainty, today, the single point from which stereotomy might have travelled to the West. Furthermore, they undermine the very idea that European stereotomy was imported from a single point of origin through a single point of entry. Quite to the contrary, the data suggests that stereotomy was a diffused, albeit uncommon, practice in the ancient and medieval East and that Western encounters with it were likely multiple, in time and space.

The evidence of these Mediterranean networks and of stereotomy's presence across a broad chronological and geographical spectrum cast doubts, too, on the timing that Viollet-le-Duc and Sanabria propose for stereotomy's conquest of Europe. There is no reason to believe that the art's development hinged on the Córdoba caliphs or the crusaders. In fact, the data collected here shows that it did not. By the end of the eleventh century, stereotomic vaults had been employed in at least thirty buildings across continental Europe and the Maghreb, including in modern France, Italy, Spain, Croatia, and Tunisia (Fig. 13 and link to online Map 1). These buildings make up more than a fourth of those dating from antiquity through the eleventh century accounted for here (113 in total); they also showcase a variety of complex vault-types, including groin vaults, arches opened in curved walls, skew arches, domes and semi-domes, annular vaults, lunettes opening in barrel vaults, and trumpet vaults. All of these vaults not only predate the crusaders' expeditions, but a majority of them also anticipate by several centuries Al-Hakam II's interventions in Córdoba Cathedral (961-76). Examples include the groin vaults in the Mérida Roman theatre and in the Mausoleum of Theodoric in Ravenna, the dome in the Tomb of Ummidia Quadratilla in Cassino, the semi-dome in the Church of Santa María de Melque in San Martín de Montalbán, the annular vault of the Saint Lubin crypt in Chartres Cathedral, and the dome on trumpet vaults in the Great Mosque of Sousse (Fig. 14).

These ancient and early medieval vaults were neither too far nor too few to be known by later European practitioners. Most of them were still standing and unencumbered. Furthermore, they appear to have been studied, reproduced, and circulated on paper, as evidenced by a number of sixteenth-century drawings, including Baldassare Peruzzi's and Giovannantonio Dosio's drawings of the skew arch of the Arco dei Pantani, in the Forum Augustum, Maarten van Heemskerck's detailed sketch of the Colosseum's conical arches inserted in curved walls, and 
Antonio da Sangallo the Younger's study of the funerary monument of Ummidia Quadratilla, in Cassino, which is accompanied by text stating that the building is 'made of stone, inside and out' (Fig. 15). ${ }^{26}$

Moreover, the above-mentioned vaults were substantially more complex in their geometries than those cited by Viollet-le-Duc, Sanabria, and Pérouse de Montclos as proof of the European discovery of stereotomy. The arches and ribs at Vézelay, cited by Viollet-le-Duc, are single-plane, linear structures; the stonecutting for these would have presented no stereotomic challenge at all, and the same is true of the crisscrossing rib domes of Córdoba's Cathedral mentioned by Sanabria, which, taken separately, are single-plane arches whose voussoirs' shapes are provided by the plans and sections of the vaults (Fig. 8 and 9). The only relatively complex pieces in the Córdoba vaults are the voussoirs located at the ribs' crossings, but their geometries are easily reduced to intersections of plane surfaces. Similarly, the ancient Roman barrel vaults of the Nîmes and Arles region mentioned by Pérouse de Montclos pose no more difficulty in execution than the single simple arches that compose them (Fig. 16). With the exception of the arches opened in the round walls of the amphitheaters of Arles and Nîmes (which were also featured in other ancient Roman amphitheaters, such as Pula, Verona, Salona, El Jem, and, of course, the Colosseum), none of these examples is, actually, of any particular relevance in the history of geometrically complex vaulted structures.

Stereotomy may have been widespread across the ancient and medieval Mediterranean well beyond what today's limited knowledge may suggest. What we know for certain is that it flourished in twelfth-century Europe: the data collected here shows at least 105 buildings featuring newly erected stereotomic vaults, for a total of 249 vaults (Fig. 17 and link to online Map 2). This proliferation of vaults is likely one of the factors that persuaded historians to associate stereotomy with the travels of the crusaders. What I would suggest, however, is that stereotomy was not imported by the crusaders but benefited, rather, from their expeditions in the same way that architectural practice in general did. All of Europe at the time of the Crusades was characterized by unprecedented growth in building activity, due to renewed religious fervor and the foundation of the mendicant orders, on the one hand, and, on the other hand, to the increased dangers associated with travels to the Holy Land, which prompted the establishment of alternative pilgrimage destinations on European soil. That is to say, the abundance of twelfth-century stereotomic vaults was

26 '...una antichaglia ouero sepoltura di pietra tutto dentro e fora', Uffizi, Florence, GDSU $1171 \mathrm{~A} \mathrm{v}$. The drawings cited here, as well as other examples, are available in the online database of the Census of Antique Works of Art and Architecture Known in the Renaissance, http://www.census.de. 
likely due not to the purported novelty of the technique, but to the abundance of newly erected, enlarged, and refurbished religious buildings in that century overall.

Stylistic and structural choices also contributed to the diffusion of stereotomy at this time: Romanesque architecture, which dominated Western Europe from the mid-eleventh century through most of the twelfth, is often characterized by thick-walled, vaulted, bare stonemasonry masses employed to define spaces whose design relies on fundamental geometries such as that of the square, the circle, and the sphere. Because of these distinctive features, Romanesque architecture was an ideal environment for the growth of stereotomic practice. The same is not true of Gothic architecture, which relies on skeletal systems that are typically non-stereotomic, even though they are built in stone. As I touched on earlier in this essay, the only custom-cut elements of a typical Gothic rib vault are the voussoirs that compose the ribs, and since these ribs are linear elements lying on vertical planes, the plan and section of the vault provide the shapes of their voussoirs.

It is no surprise, then, that production of stereotomic vaults diminished significantly during the thirteenth century, when Gothic architecture proliferated across the European continent, and it remained negligible through the fourteenth and most of the fifteenth century, as long as the Gothic style led the way in new construction. Even the most complex of Gothic and Flamboyant multi-rib vaults-for example, the tierceron vaults of St. Riquier, the segmentalrib vaults in the vestibule of the Château de Chenonceau, and vaults featuring skew ribs, as in the Chapelle de la Vierge in the Parisian Church of St. Germain l'Auxerrois (Fig. 18)-were produced with non-stereotomic techniques, on the basis of plans and sections alone. While it is true that the geometries of these vault types are complex because they involve three-dimensional reticulations and spatial curves (i.e. curves that do not lie on a single plane), scholars have shown that medieval practitioners solved them with two-dimensional rather than three-dimensional geometry. That is, instead of construing tiercerons and skew ribs as parts of three-dimensional surfaces that need developing, as a stereotomist would, they construed them as linear objects connecting points in space along predetermined curvatures according to the prinzipalbogen (principal arch) method. ${ }^{27}$ We see this illustrated in the Codex Miniatus 3 (also known as the Dresden Sketchbook of Vault Projection, ca. 1544-67), where the plan of the vault and

27 On the prinzipalbogen method, see especially François Bucher, 'The Dresden Sketchbook of Vault Projection', in György Rózsa (ed.), Évolution générale et développements régionaux en histoire de l'art: actes du $22^{e}$ congrès international d'histoire de l'art, Budapest 1969, Budapest: Akadémiai Kiadó, 1972, vol. 1, pp. 527-537 and vol. 3, pp. 163-172 and Norbert Nussbaum and Sabine Lepsky, Das gotische Gewölbe: eine Geschichte seiner Form und Konstruktion, München: Deutscher Kunstverlag, 1999, pp. 175-182. 
the curvature of the chosen principal arch (which is a virtual arch, not a built feature of the vault itself) are the only elements necessary to determine the shape of the ribs and of the voussoirs that compose them (Fig. 19). The prinzipalbogen method was employed not only in the German-speaking areas of central Europe, where it was likely developed in the fifteenth century, but in Britain, France, Spain, and Portugal, and as late as the eighteenth century. ${ }^{28}$ By providing two-dimensional, plan-and-section solutions to three-dimensional problems, the prinzipalbogen method points to the ingenuity of late-medieval stonecutters; it is not proof, however, that these same practitioners mastered the three-dimensional geometry skills required by stereotomy.

The resurgence of stereotomic practice and theory in early modern Europe after the long Gothic hiatus, and the fascination the art continued to exercise over generations of patrons, architects, and mathematicians are complex and little-understood phenomena that deserve to be treated further as well as separately. It seems reasonable to suggest, however, that just as European stereotomy did not develop along an uninterrupted line of progress from the twelfth-century onward, as postulated by traditional historiography, its flourishing in the sixteenth century can be described as its own kind of renaissance.

Looking again at the geographical data, we find no support for the claim advanced by Viollet-le-Duc and Pérouse de Montclos that medieval stereotomy is a quintessentially French art-'the touchstone of the French manière', according to Pérouse de Montclos. ${ }^{29}$ France was not alone in boasting a twelfth-century proliferation of stereotomy; indeed, stereotomic vaults were not numerically more significant in France than in many of the places where they can be traced in Europe, including the Italian and Iberian peninsulas and the Western Mediterranean islands (Fig. 17 and link to online Map 2). Similarly, the geographical distribution of vault types does not identify France as a more productive incubator of forms than its neighbors: we find that $57 \%$ of the 249 twelfth-century European vaults mapped here are domes and semi-domes, and they are evenly distributed between France, Italy, and Spain, and present also in Portugal and Germany. The same is true of the other complex-shape types that appear in relevant quantities, such as trumpet vaults (17\% of the total count), which were as popular in twelfth-century Spain as they were in France, and groin vaults ( $13 \%$ of the total count), the majority of which are found in Sardinia and Sicily.

28 Illustrations of the same method are also found in the Sketchbook of Master WG (1560-72, Frankfurt, Städelsches Kunstinstitut, ms. 8-494), as well as in the sixteenth-century treatises by de L'Orme (Premier tome, ff. 107 ${ }^{\mathrm{r}}-109^{\mathrm{v}}$ ) and Vandelvira (El tratado de arquitectura, vol. 2, f. $96^{\mathrm{v}}$ ).

29 Pérouse de Montclos, L'architecture à la française, rev. $2^{\text {nd }}$ ed., p. 79. 
With the phasing out of Romanesque massive masonries, the number of newly-built stereotomic vaults dramatically decreased in France as it did elsewhere and continued to decrease for the next two centuries. While Philippe Potié posits (with no further discussion or data in support of his argument) that late medieval French stereotomy was a firmly established toolkit of vault types and techniques-'the art of stonecutting is almost definitively fixed by the end of the fourteenth century: trumpet vaults, domes, and arriere-voussures only go through secondary, formal developments after this date'-the data gathered by Pérouse de Montclos himself shows, to the contrary, that if stereotomic knowledge had ever taken such a fixed form amongst French practitioners, it also had been drastically jeopardized by the middle of the fifteenth century. ${ }^{30}$ According to Pérouse de Montclos's survey, only six new vaults of complex geometry were built on French soil during the second half of the fifteenth century: four trumpet vaults, all of the same type (at the Hôtel de Cluny in Paris, at the Ancienne Université in Poitiers, and at the Château d'Armentières); one helical barrel vault of the Vis Saint Gilles type in Sens Cathedral; and one dome, no longer extant, recorded at the chapel of the Château des Ducs de Bourbon in Moulins, for which we lack documentation showing whether it was, in fact, stereotomic or not. ${ }^{31}$ Arrière-voussures and skew arches may have escaped Pérouse de Montclos's survey-because they rarely take monumental forms and are mostly used for doors and windows, which exposes them to a higher chance of modification over time than monumental vaults or staircases-but nonetheless it is evident that late fifteenth-century France was not exactly a hotbed of complex-geometry stereotomic vaults: no stereotomic domes, semi-domes, lunettes, groin vaults, cloister vaults à enchevêtrements (the only type of cloister vault that poses a stereotomic challenge), or annular vaults are documented for this period. In fact, of the many vaults and vault types illustrated by de L'Orme in the Premier Tome, only a handful of them seems to have been available, less than a century earlier, to French practitioners and patrons.

It was outside of France that the art of stereotomy flourished in the late Middle Ages, in particular in the region of Valencia, where we find the highest concentration of stereotomic vaults known to date for fifteenth-century Europe,

30 Potié, 'Le tracé d'épure', p. 149.

31 Pérouse de Montclos, L'architecture à la française, rev. $2^{\text {nd }}$ ed., pp. 284-316. On the doubts about the stereotomic nature of the dome in Moulins, see Ibid., p. 148. Pérouse de Montclos does not pretend to have established a comprehensive list of stereotomic vaults, and it is of course likely that more than five stereotomic vaults were built in French territory during the second half of the fifteenth century. Yet since the sources and methods he employs to collect data on fifteenth-century France are the same that he employs for the rest of his survey, it is reasonable to expect errors and missing data (including non-extant vaults) to be distributed across the chronological spectrum covered by his study, and, therefore, for their relative significance to be acceptably limited. 
and in Cairo, where the numerous extant Mamluk domes testify to an advanced mastery of complex-geometry vaulting (Fig. 20 and link to online Map 2)..$^{32}$ In Valencia in this period, stereotomic vaults were produced in the circles of architects such as Francesc Baldomar and Pere Compte for buildings such as the Convent of Santo Domingo, the Cathedral, the Lonja de la Seda, and the Real Monasterio de Santa Maria. They encompassed a variety of types, including skew and corner arches, inclined barrel vaults, trumpet vaults, groin vaults, domes and pendentives, and floating staircases supported by composite vaults. ${ }^{33}$ It would seem that fifteenth-century Valencian practitioners mastered the entire spectrum of vault types later illustrated by de L'Orme in his Premier Tome, with the sole exception of helical barrel vaults of the Vis Saint Gilles type-and in the fifteenth century we find these only in Barcelona (cathedral, 1410), Noto (castle, ca. 1430), Naples (Castel Nuovo, ca. 1450-54), and Sens (after 1492). ${ }^{34}$ Similarly, the Cairo domes, which combine flawless voussoirs and joints with complex sculpted patterns (which some scholars believe were carved ahead of mounting, adding complexity, of course, to the geometric operations necessary to cut the voussoirs) provide numerous precedents for a technique that would not appear in France until more than a century later, in the dome of the chapel of the Château d'Anet (1549-52, Fig. 4). ${ }^{35}$

32 According to Bernard O'Kane, more than sixty pre-modern masonry domes have survived in Cairo (Bernard O'Kane, 'The Carved Stone Domes of Cairo' [paper presented at the conference 'Masons at Work', University of Pennsylvania, 30 March-1 April 2012, http://www.sas.upenn.edu/ancient/publications.html], p. 1). For an overview, see Kessler, The Carved Masonry Domes of Mediaeval Cairo.

33 On the practice of stereotomy in Valencia during the second half of the fifteenth century, see Arturo Zaragozá Catalán and Mercedes Gómez Ferrer, 'Costruyendo en la Valencia cuatrocentista: la fundación del gremio de canteros', in Id. (eds.), Pere Compte Arquitecto, Valencia: Ajuntament de Valencia, 2007, pp. 213-237; Zaragozá Catalán, El arte de corte de piedras; and Navarro Fajardo, Bóvedas valencianas.

34 On the Vis Saint Gilles in Barcelona, see Miguel Sobrino González, 'Barcelona: las razones de una catedral singular', Goya 307-308 (2005), p. 202. For the information about the Vis Saint Gilles in Noto and Naples, I am indebted to Marco Rosario Nobile. It is worth noting that the Valencian vaults cited here were executed decades in advance of the arrival, in Spain, of the sixteenthcentury French masters which are often attributed with the importation of stereotomic knowledge in the Iberian peninsula, such as Étienne Jamet, Sébastien Bougereau, and Benoît Augier. See Arturo Zaragozá Catalán, José Calvo López, and Pau Natividad Vivó, 'Stereotomic Exchanges between Iberia and France in the $16^{\text {th }}$ Century: Benoit Augier, Valencian Stairways and the Escalier de Toulouse', in Robert Carvais et al. (eds.), Nuts \& Bolts of Construction History: Culture, Technology and Society: Proceedings of the Fourth International Congress on Construction History, Paris, 3-7 July 2012, Paris: Picard, 2012, vol. 1, pp. 385-392.

35 On the issue of whether the sculpted patterns of Mamluk stereotomic domes were executed before or after mounting, see especially Barbara Cipriani, Development of Construction Techniques in the Mamluk Domes of Cairo, Master's thesis, Massachusetts Institute of Technology, 2005; Barbara Cipriani and Wanda W. Lau, 'Construction Techniques in Medieval Cairo: The Domes of Mamluk Mausolea (1250 A.D.-1517 A.D.)', in Malcolm Dunkeld (ed.), Proceedings of the Second 
Traditional theories about the origins of stereotomy and its developments in medieval Europe contribute to a well-established historiographical tradition, which for now more than a century has centered on whether early medieval European architecture was the product of a continuous western tradition rooted in Roman antiquity or whether it was produced by a disruption of that tradition, the encounter with external, Eastern practices and forms that reached Europe via northern, Christian routes through the Balkans or via southern, Islamic routes through Northern Africa. ${ }^{36}$ Although this debate has been productive in a number of ways-showing, for instance, that practices and practitioners could travel far and long across the Mediterranean Sea, and that abandoned forms and longforgotten techniques could be revived if interest was renewed among local practitioners in the absence of external stimuli-its theoretical framework is unfit for a modern history of stereotomy. Part of the problem is that the debate originated around issues of transfer of formal architectural features (i.e. vault shapes rather than construction materials and practices) which do not always, or easily, apply to the world of techniques. Another issue is that stereotomy, as a marginal art, calls for caution when attempting to outline precise narratives of origin or transfer: no matter what geographic area or historical period is being considered, stereotomic vaults tend to be such a small portion of the built environment that the destruction of a handful of vaults can swipe away any trace of stereotomic practice in a given region, culture, or time period, thus significantly skewing the historian's data. Perhaps the biggest issue is that the kind of pre-Braudelian narratives of the Mediterranean that have informed this historiographical tradition-narratives that focus on punctual, large-scale events, and linear transfers-prove inadequate to capture the complex networks of

International Congress on Construction History, Queen's College, Cambridge University 29 March-2 April 2006, Cambridge: Construction History Society, 2006, pp. 695-716; Christophe Bouleau, 'Bâtir une coupole en pierre de taille', Annales Islamologiques 41 (2007), pp. 209-228; O'Kane, 'The Carved Stone Domes of Cairo'; and Ahmed Wahby and Dina Montasser, 'The Ornamented Domes of Cairo: The Mamluk Mason's Challenge', paper presented at the conference 'Masons at Work', University of Pennsylvania, 30 March-1 April 2012, http://www.sas.upenn.edu/ancient/ publications.html.

36 Among the fundamental texts on either side of this debate: Auguste Choisy, Histoire de l'architecture, Paris: Gauthier-Villars, 1899, vol. 2, pp. 80-88; Josef Strzygowski, Orient oder Rom: Beiträge zur Geschichte der Spätantiken und Frühchristlichen Kunst, Leipzig: J.C. Hinrichs'sche Buchhandlung, 1901 as well as the excellent historiographical analysis by Christina Maranci, Medieval Armenian Architecture: Constructions of Race and Nation, Leuven: Peeters, 2001; Gustavo Giovannoni, 'L'organismo a volta dall'architettura romana alla bizantina', Felix Ravenna 27, 1 (1939), pp. 5-30; Id., 'Volte romane e volte bizantine', in Atti del V Congresso Internazionale di Studi Bizantini: Roma 20-26 settembre 1936, Rome: Tipografie del Senato, 1940, vol. 2, pp. 133-138; Guglielmo De Angelis d'Ossat, 'Le Origini romane della cupola bizantina', Rivista Romana 14 (1936), pp. 3-12; and Id., Romanità delle cupole paleocristiane, Rome: Reale Istituto di Studi Romani, 1946. 
relations and the intricate and sometimes fortuitous routes through which knowledge and other goods moved across physical, cultural, and temporal borders in the ancient and medieval Mediterranean. If we look for an alternative to the national narratives of linear movements and progressive developments imagined so far by scholars, then what we know about ancient and medieval stereotomy points to a complex map of regional, small-scale events and objects distributed in an often-counterintuitive fashion across a wide chronological and geographical span. Dispersed phenomena like these are perhaps best understood within a framework of Mediterranean connectivity, the dense and far-reaching network of relationships that connected the people and civilizations who thrived and fell along the sea's shores across time and space. The yet-to-be-written history of ancient and medieval stereotomy will necessarily develop as a transnational history encompassing networks of exchanges and contacts, smallscale communities and phenomena, as well as gaps, interrupted developments, independent discoveries, and re-discoveries in the many places and moments, across the connected Mediterranean, where vaulting was a practice and stone a commodity. 


\section{Illustrations}

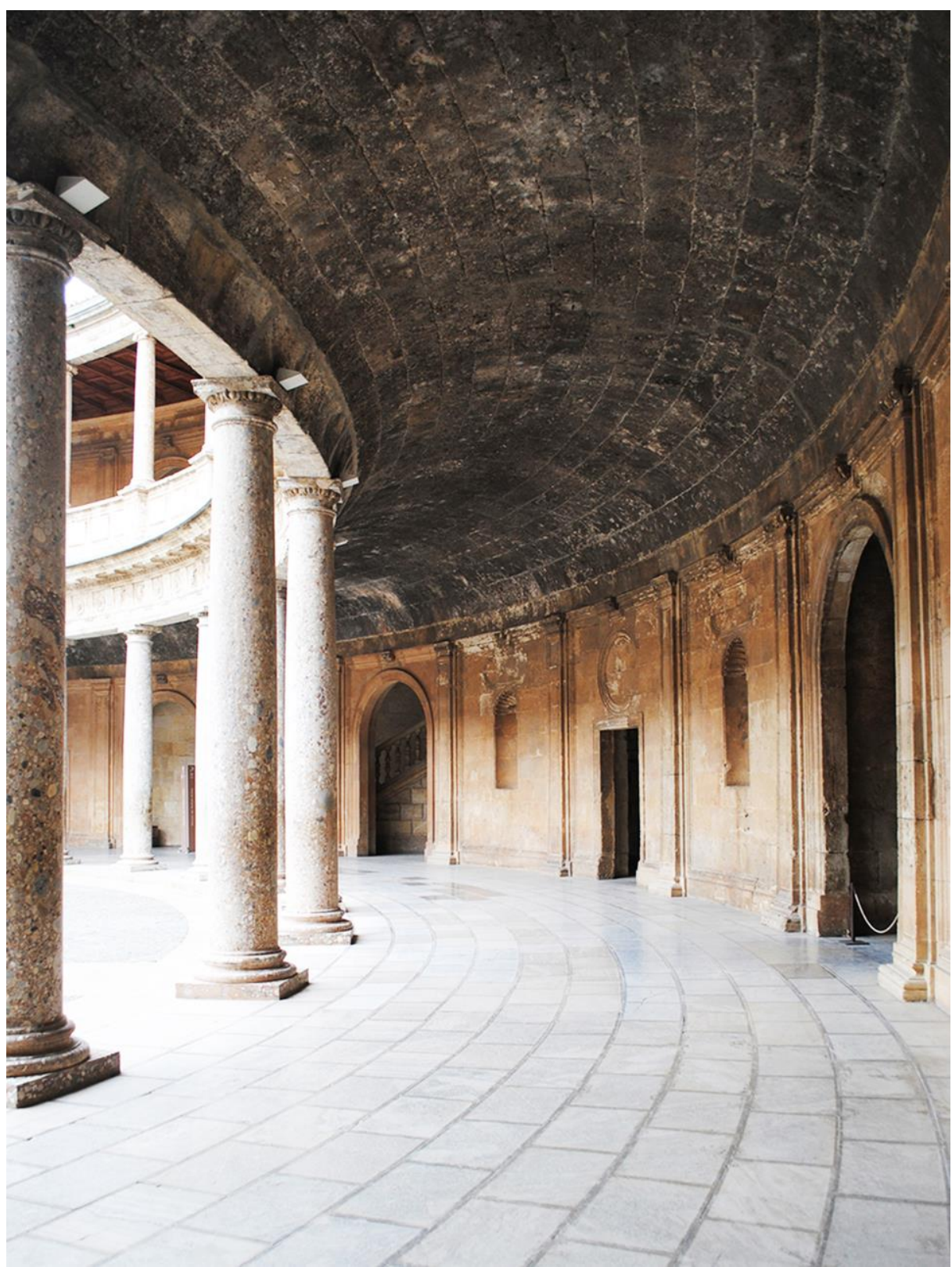

Fig. 1. Pedro and Luis Machuca, annular stereotomic vault, 1562-69, courtyard, Palace of Charles V, Granada. 


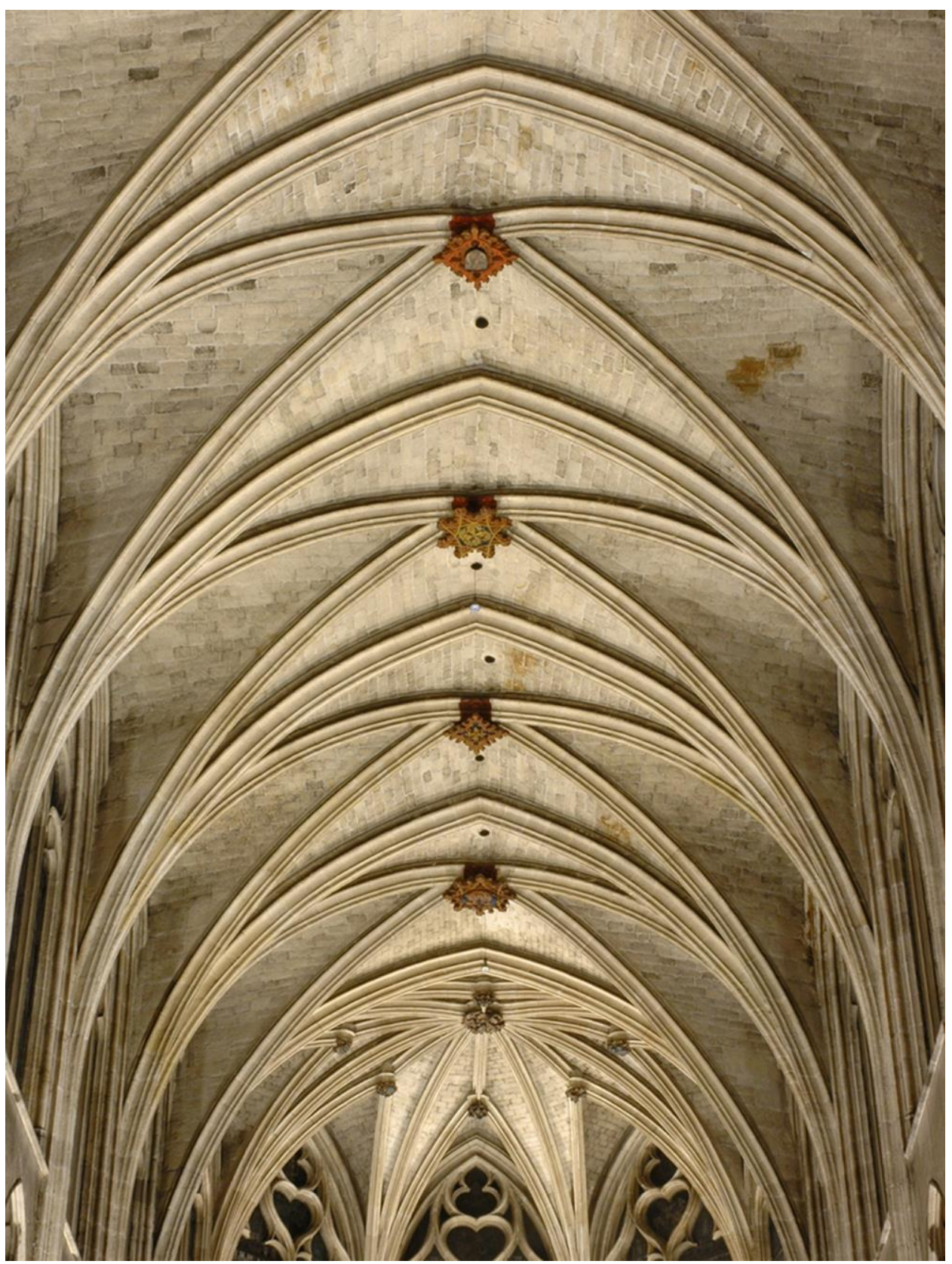

Fig. 2. Non-stereotomic rib vaults, Church of Saint Séverin, Paris, second half of the $15^{\text {th }}$ cent. 


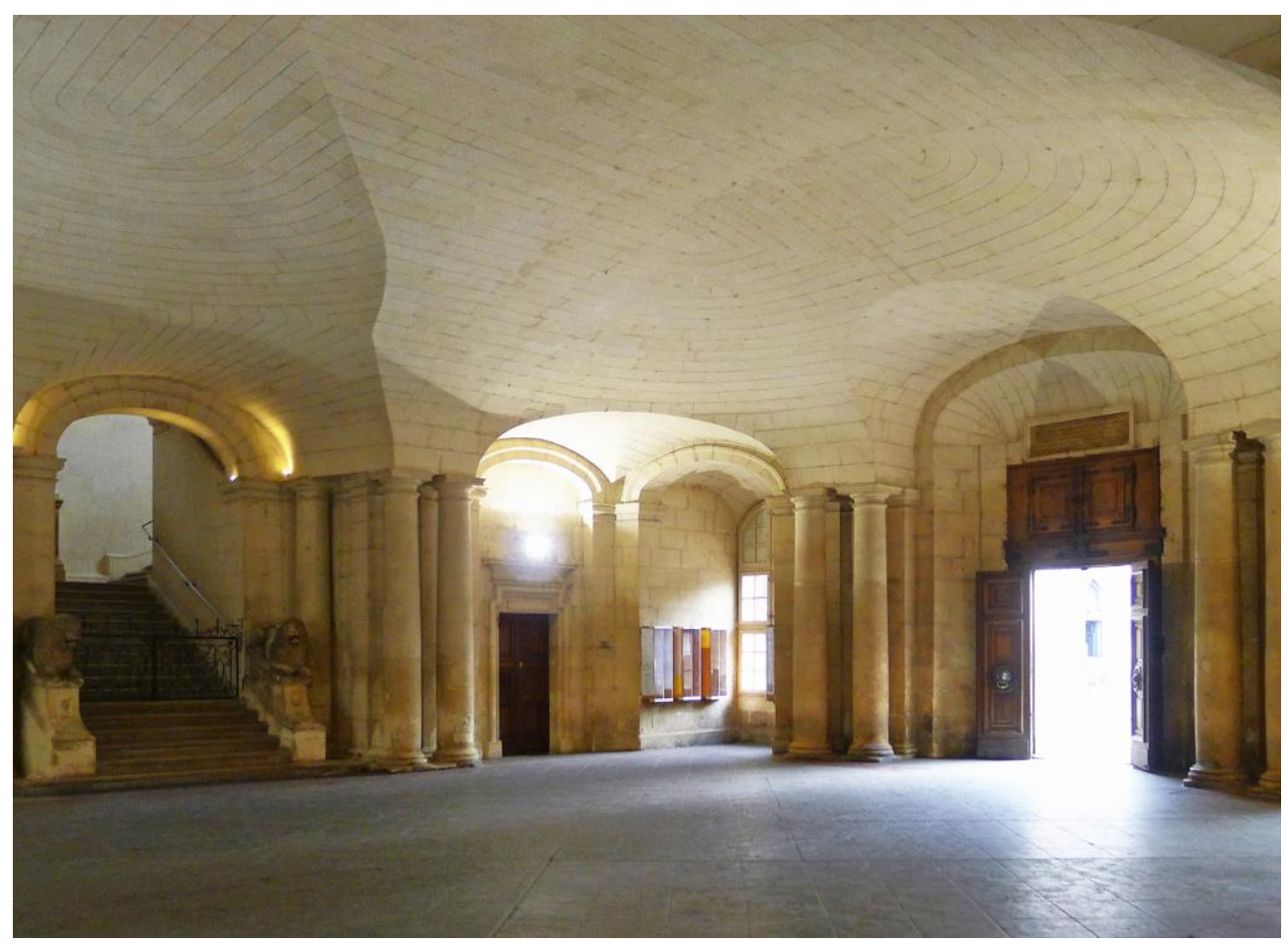

Fig. 3. Jules Hardouin-Mansart, composite vault, 1673-76, City Hall, Arles.
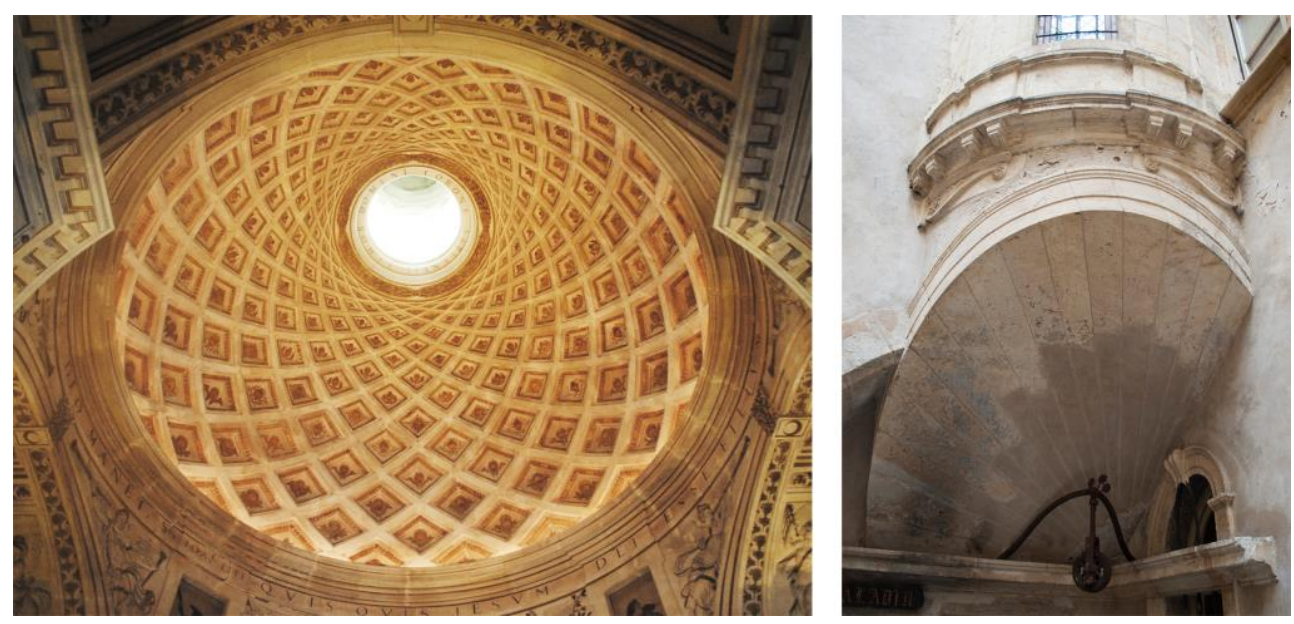

Fig. 4. Left: Philibert de L'Orme, dome, 1549-52, chapel, Château d'Anet. Right: Philibert de L'Orme, trumpet vault, 1536, Hôtel Bullioud, Lyon. 


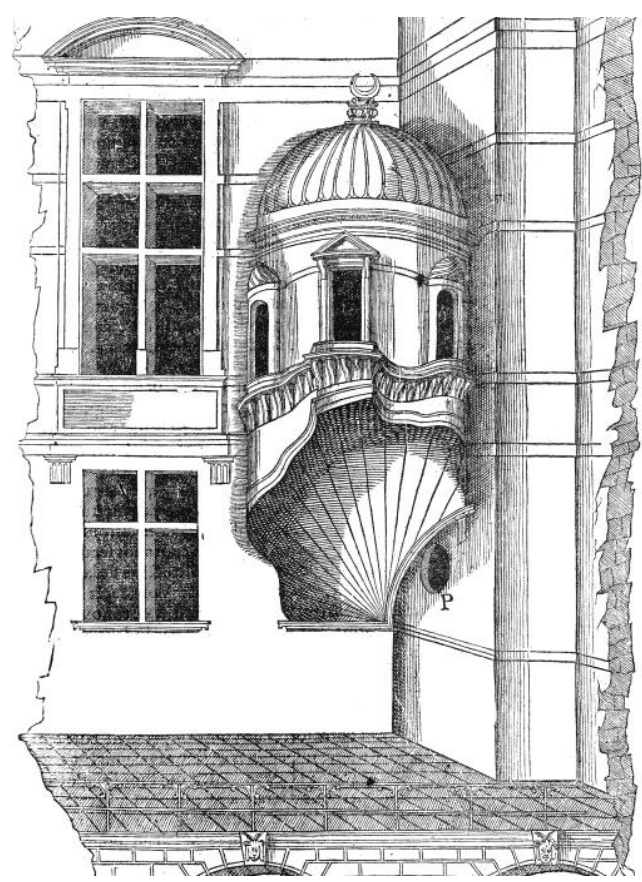

Fig. 5. Philibert de L'Orme, trumpet vault, ca. 1552, Château d'Anet (L'Orme, Premier Tome, f. 89²).
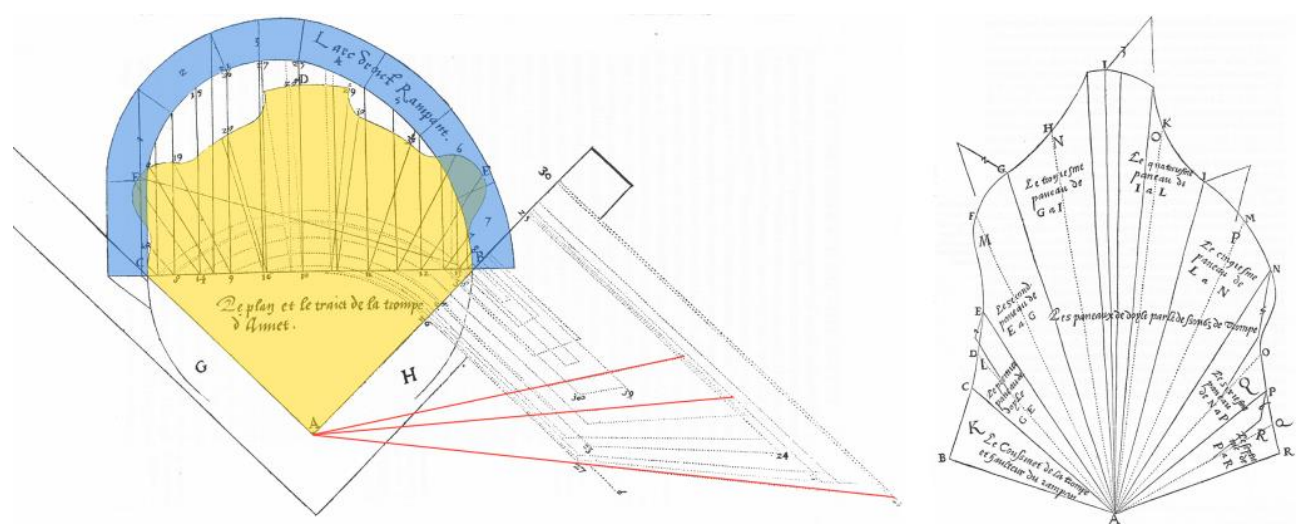

Fig. 6. Philibert de L'Orme, trumpet vault, ca. 1552, Château d'Anet (L'Orme, Premier Tome, ff. $92^{\mathrm{v}}-93^{\mathrm{r}}$ and $95^{\mathrm{v}}$ ). Left: Geometric constructions used to find the true lengths of the joint lines lying on the conic surface (in red) given the vault's plan (in yellow) and vertical section (in blue). Right: the developed conic surface of the vault. 


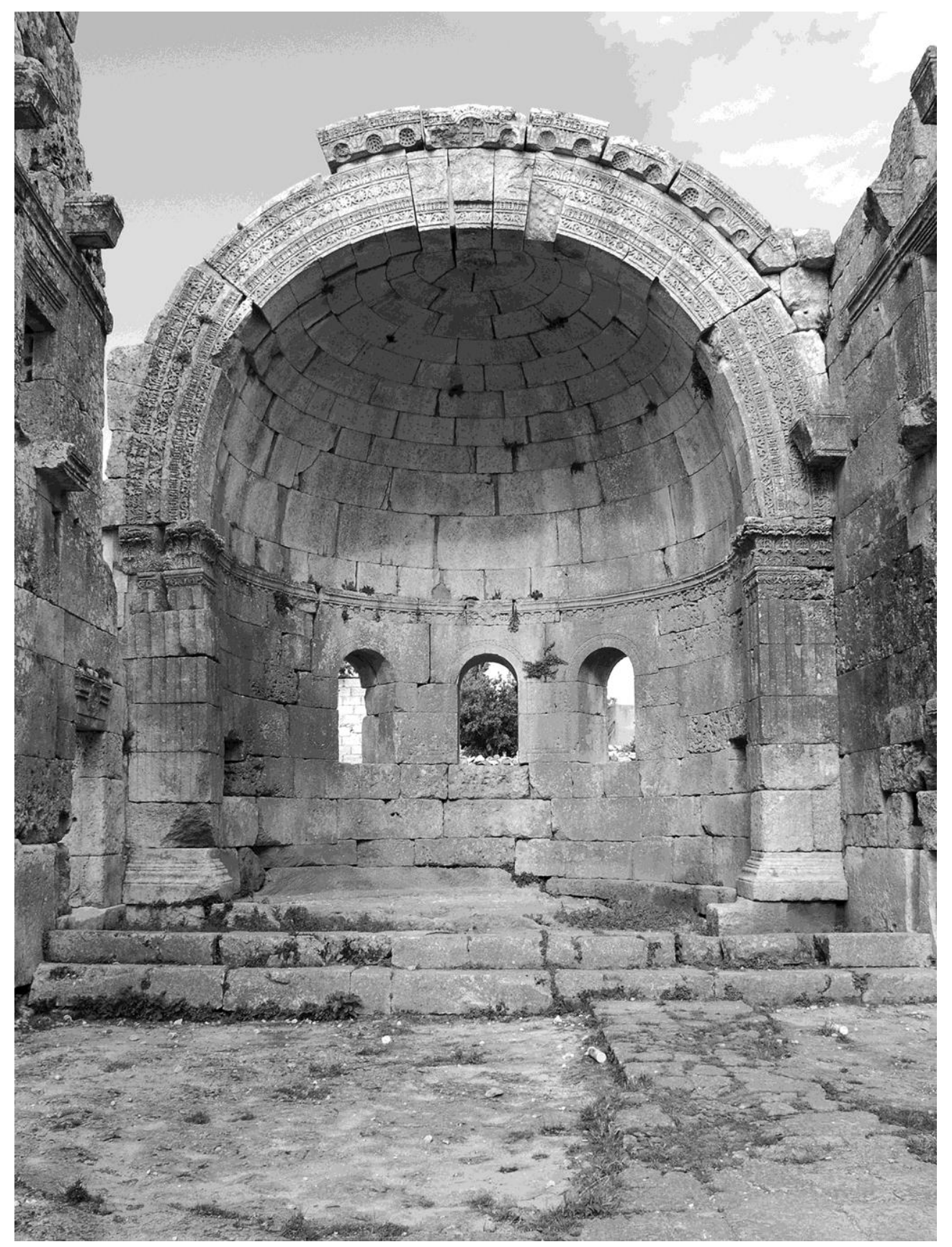

Fig. 7. Basilica of Qalb Lozeh (Idlib), $5^{\text {th }}$ cent. CE. 


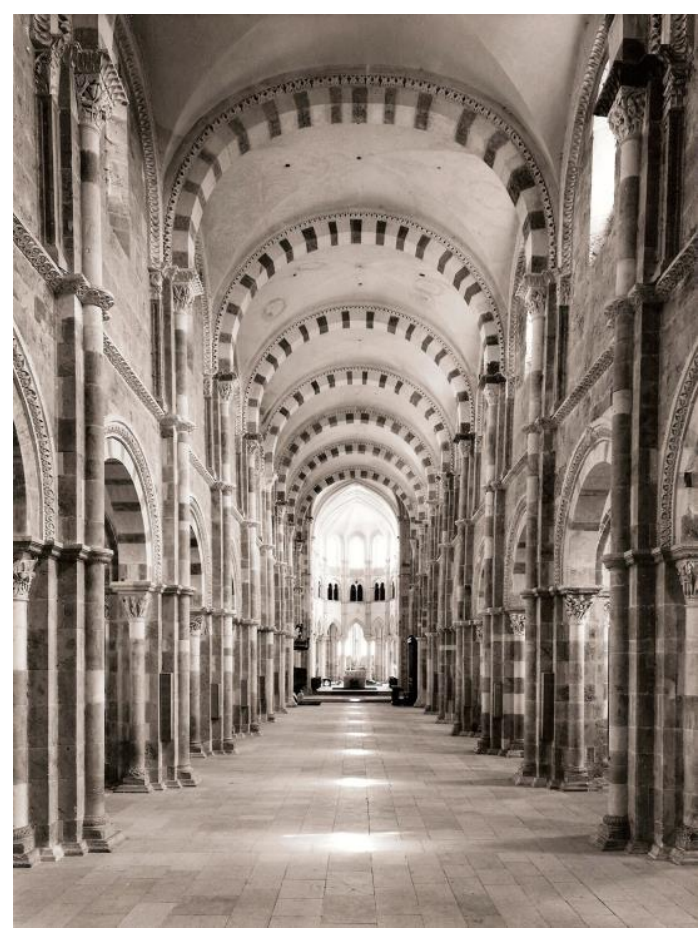

Fig. 8. Nave of the Basilica of Sainte-Marie-Madeleine, Vézelay, $12^{\text {th }}$ cent.
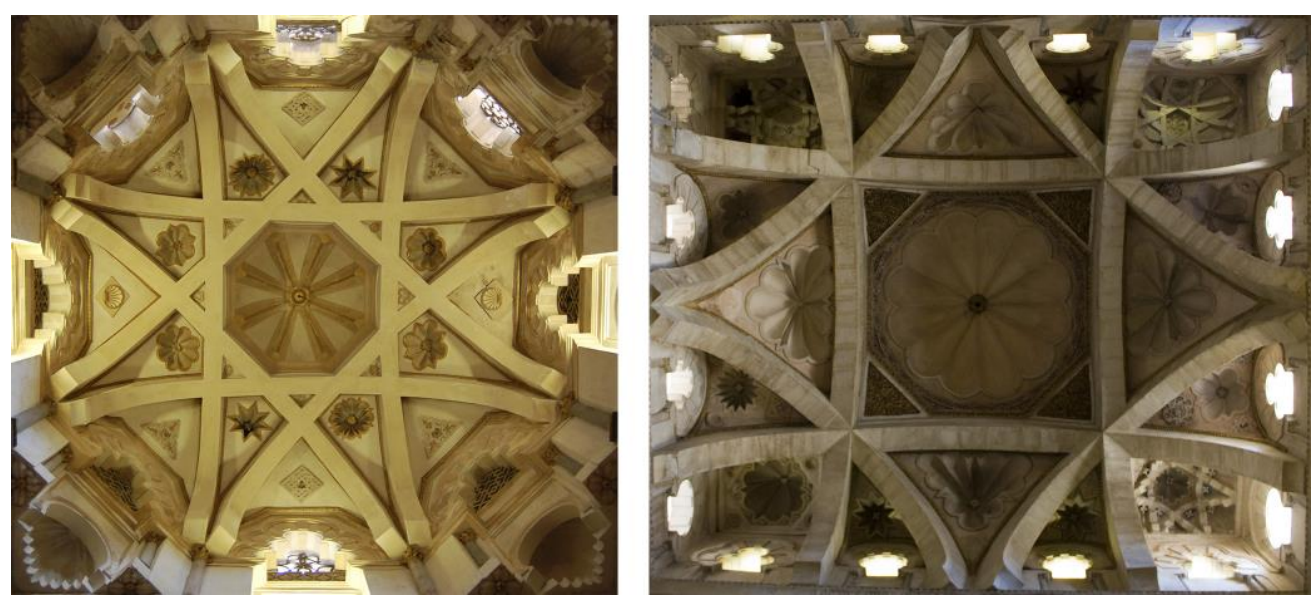

Fig. 9. Mosque-Cathedral of Cordoba. Left (a): Dome of the maqsura, 961-76. Right (b): Dome of the Villaviciosa Chapel, 1257-74. 


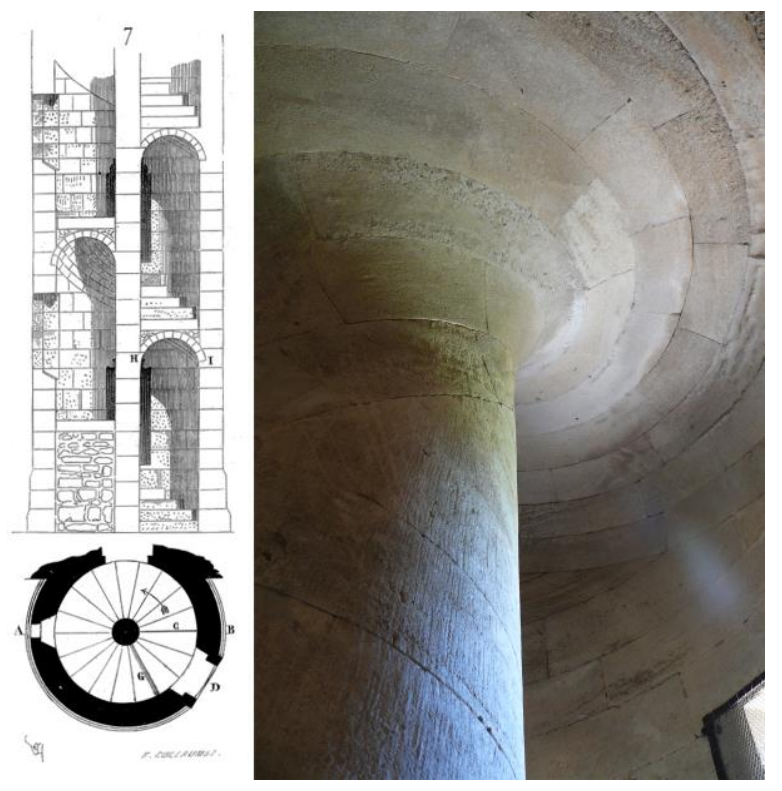

Fig. 10. Left: Plan and section of a helical barrel vault of the Vis Saint Gilles type (Viollet-le-Duc, Dictionnaire raisonné, vol. 5, p. 295). Right: Vis Saint Gilles, Abbey of Saint Gilles, $12^{\text {th }}$ cent.?

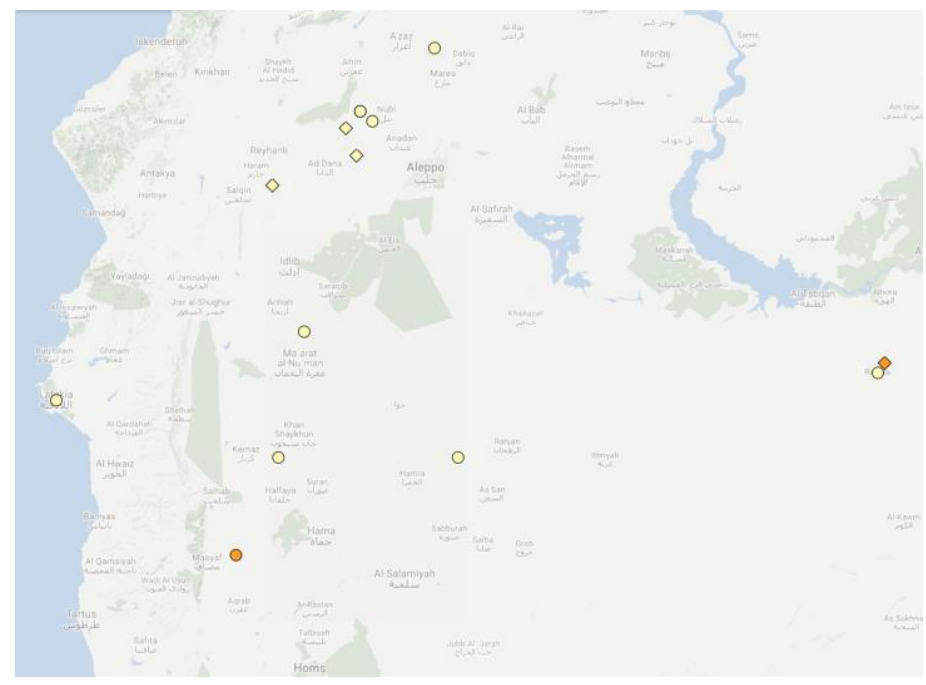

Fig. 11. Map 1 (Stereotomic vaults, $3^{\text {rd }}$ cent. BCE-11 $1^{\text {th }}$ cent. CE, https://drive.google.com/open?id=1a6fanW31YKaAbK806Dij7YzA8Bo\&usp= sharin), detail, Syria, $2^{\text {nd }}-6^{\text {th }}$ cent. CE (captured on 14 October 2016). 


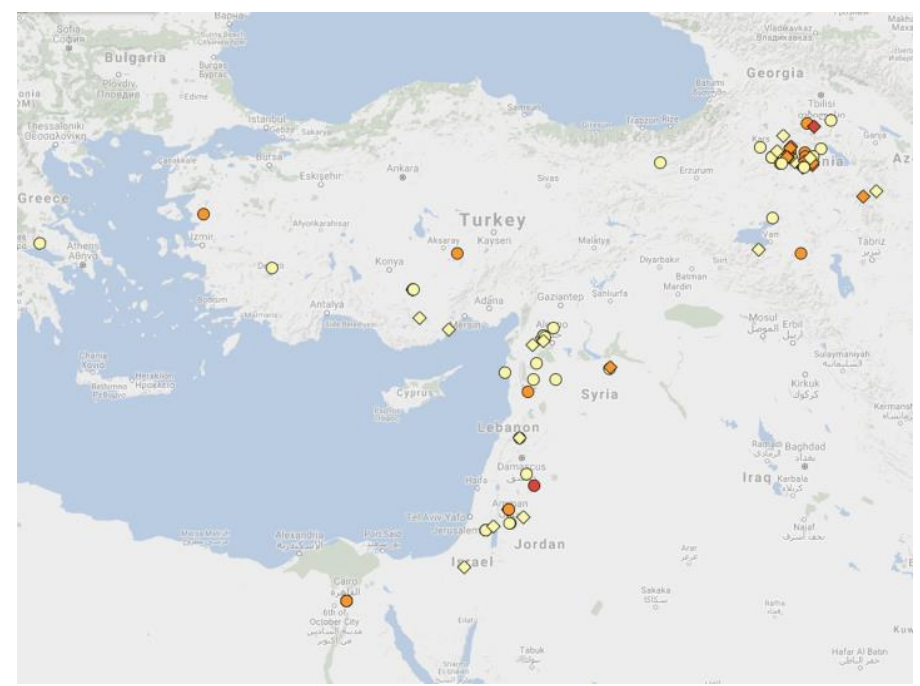

Fig. 12. Map 1 (Stereotomic vaults, $3^{\text {rd }}$ cent. BCE-11 $1^{\text {th }}$ cent. $C E$, https://drive.google.com/open?id=1a6fanW31YKaAbK806Dij7YzA8Bo\&usp= sharing), detail, Eastern Mediterranean region, $3^{\text {rd }}$ cent. BCE- $11^{\text {th }}$ cent. CE (captured on 14 October 2016).

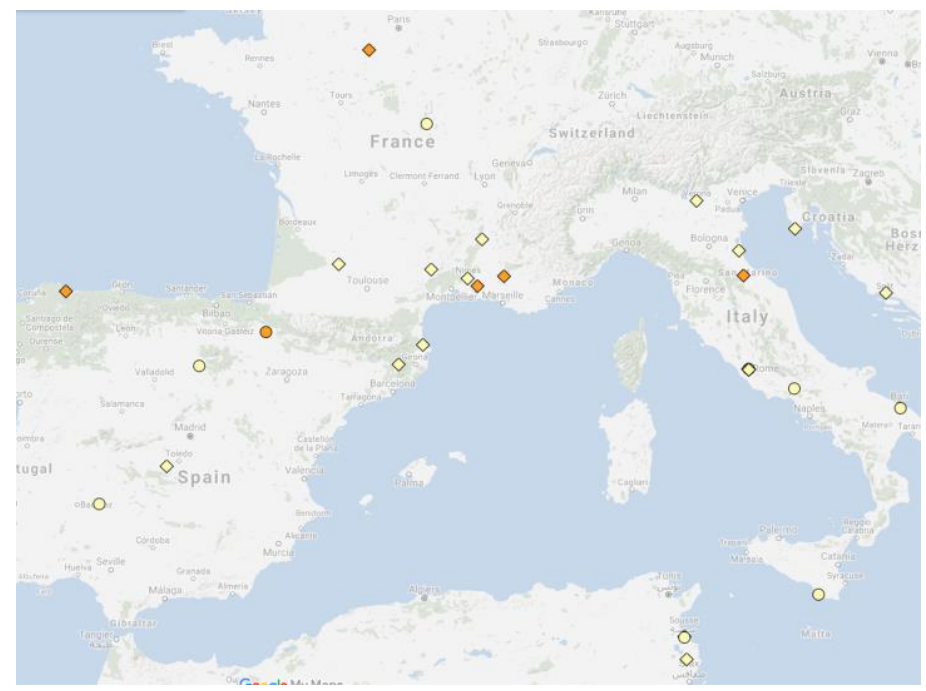

Fig. 13. Map 1 (Stereotomic vaults, $3^{\text {rd }}$ cent. BCE-11 $1^{\text {th }}$ cent. CE, https://drive.google.com/open?id=1a6fanW31YKaAbK8o6Dij7YzA8Bo\&usp= sharing), detail, Western Mediterranean region, $1^{\text {st }}$ cent. BCE- $11^{\text {th }}$ cent. CE (captured on 14 October 2016). 

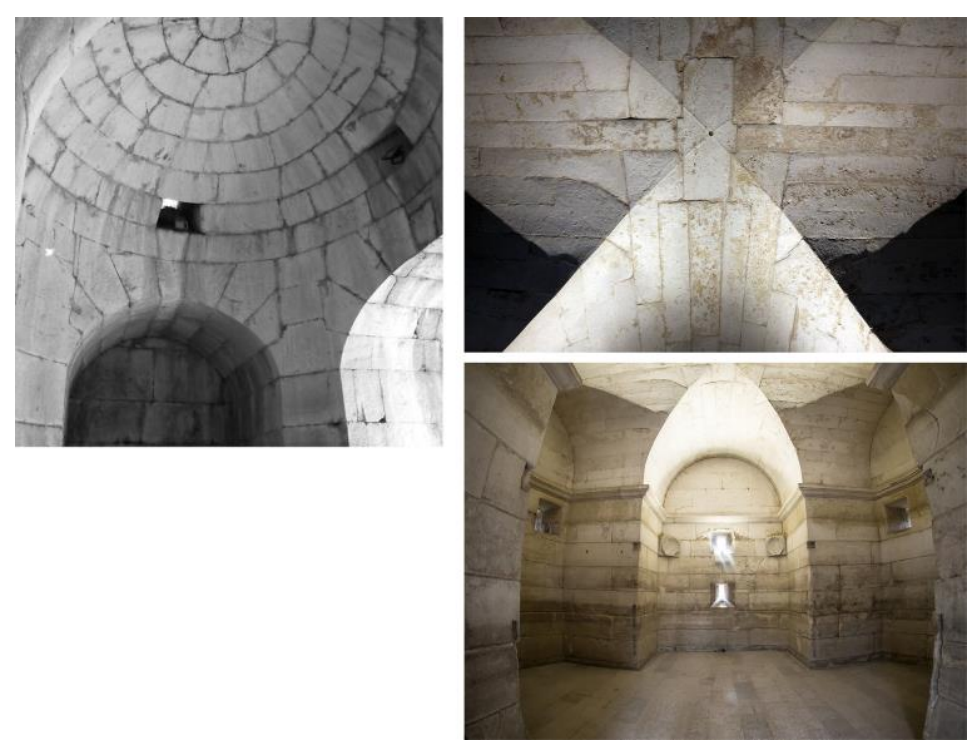

Fig. 14. Left: Dome, Tomb of Ummidia Quadratilla, Cassino, $2^{\text {nd }}$ cent. CE. Right: Groin vault, lower chamber, Mausoleum of Theodoric, Ravenna, $6^{\text {th }}$ cent. CE.
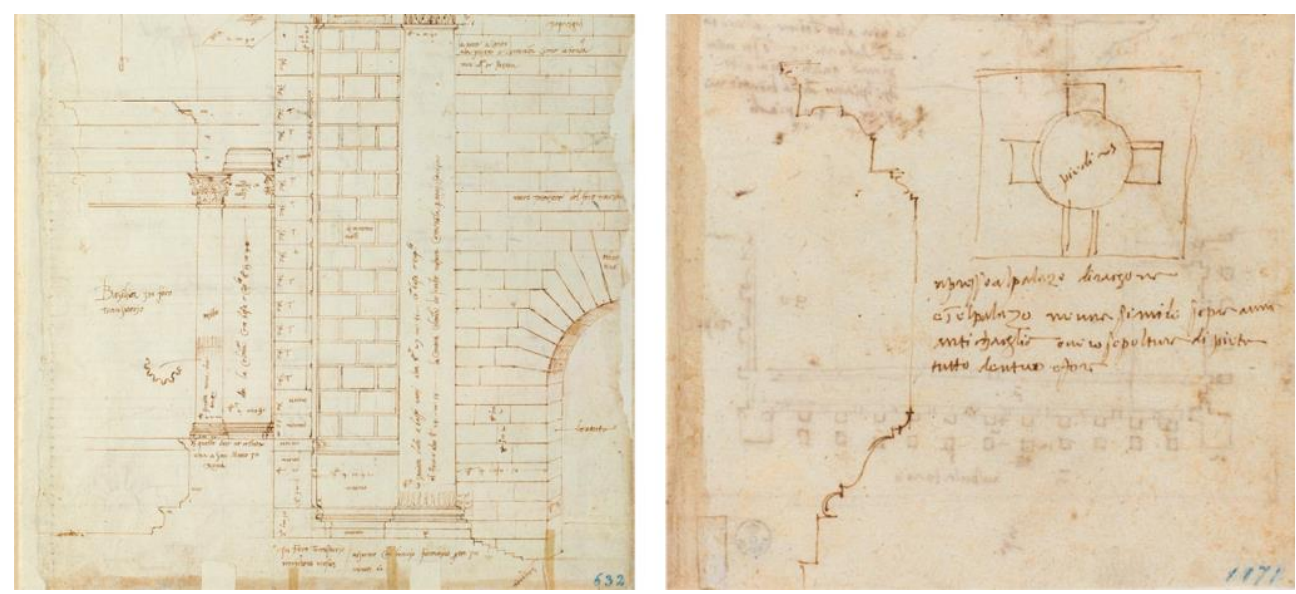

Fig. 15. Left: Baldassare Peruzzi, Arco dei Pantani, 1525-32. Uffizi, Florence, GDSU 632 A v, detail. Right: Antonio da Sangallo the Younger, Tomb of Ummidia Quadratilla, 1510-46. Uffizi, Florence, GDSU 1171 A v, detail. 


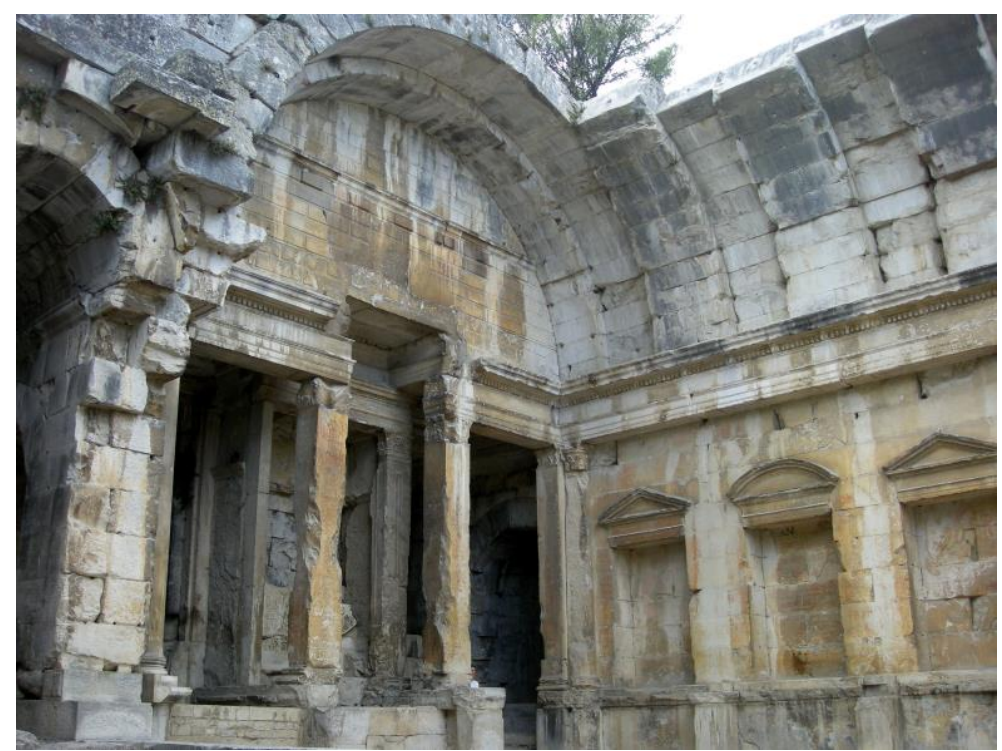

Fig. 16. Temple of Diana, Nîmes, $1^{\text {st }}$ cent. CE.

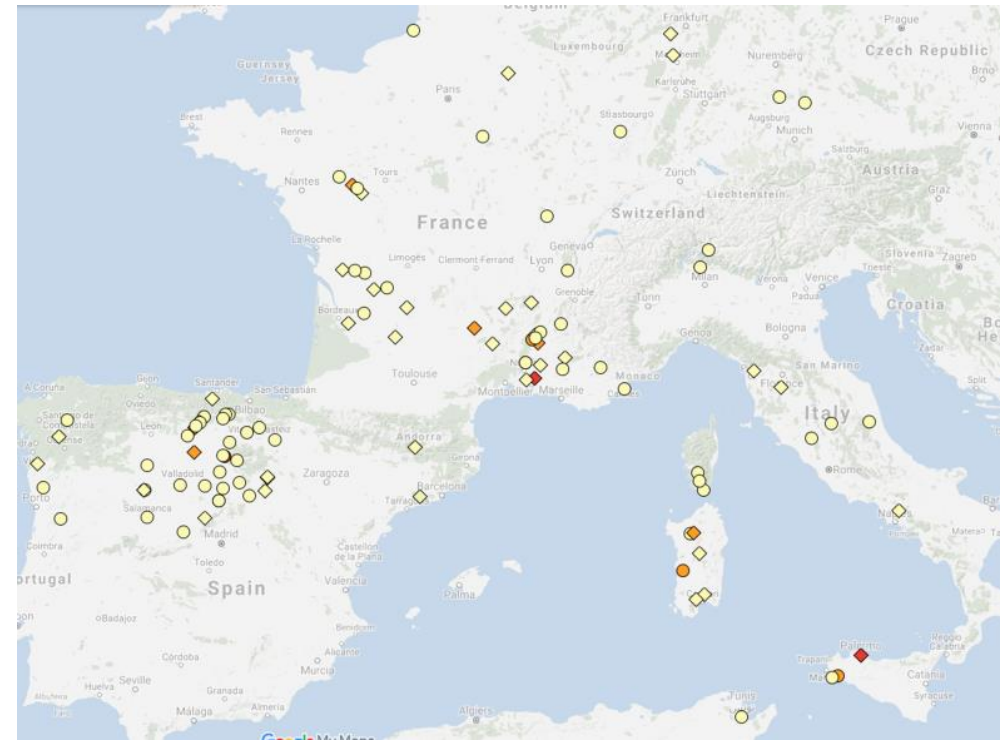

Fig. 17. Map 2 (Stereotomic vaults, $12^{\text {th }}-15^{\text {th }}$ cent. CE, https://drive.google.com/open?id=1G7c2F3FvHjix06YJ_ZrIXOnvc2c) detail, Europe, $12^{\text {th }}$ cent. CE (captured on 14 October 2016). 

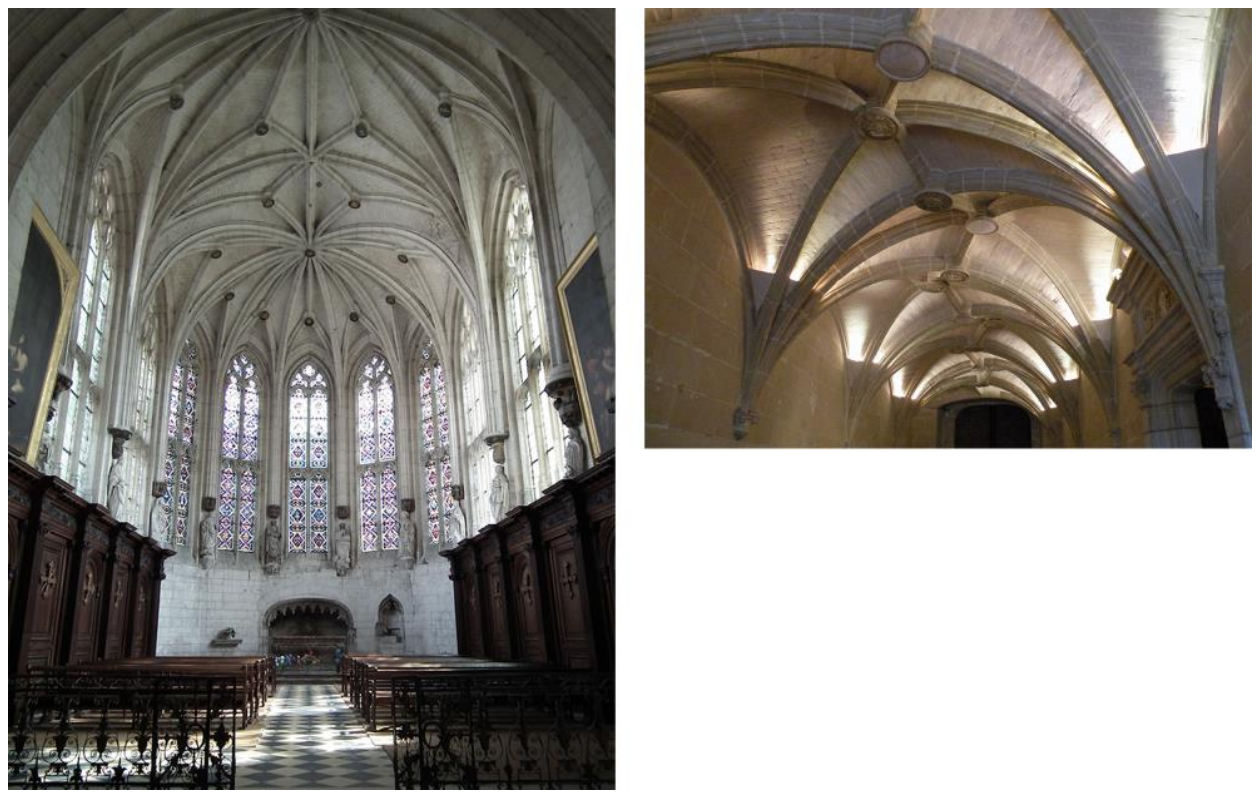

Fig. 18. Left: Segmental-rib vaults, Lady Chapel, $15^{\text {th }}$ cent., Abbey Church of St. Riquier. Right: Segmental-rib vaults, entrance hall, Château de Chenonceau, 1515-21.

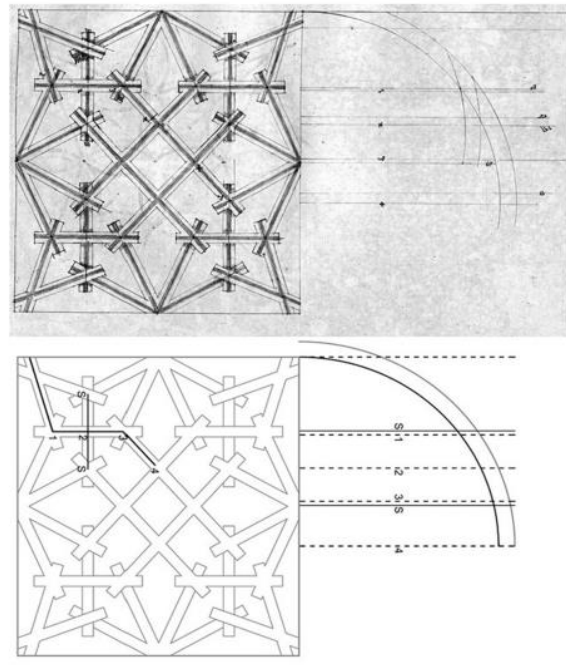

Fig. 3: Codex Miniatus 3, fol.2. Prinzipalbogen definition

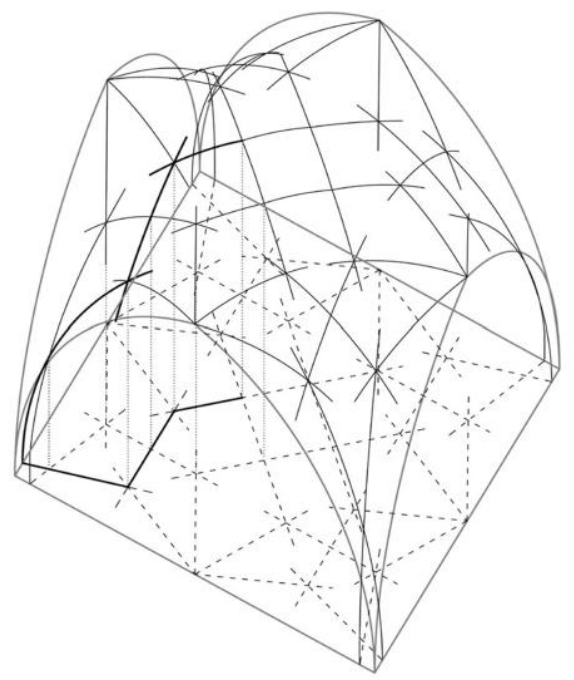

Fig. 4: Construction of the form of the previous vault.

Fig. 19. Illustration of the prinzipalbogen method (Rafael Martín Talaverano, Carmen Pérez de los Ríos, and Rosa Senent Domínguez, 'Late Gothic German Vault Design Methods and its Relationship with Spanish Ribbed Vaults', p. 86). 

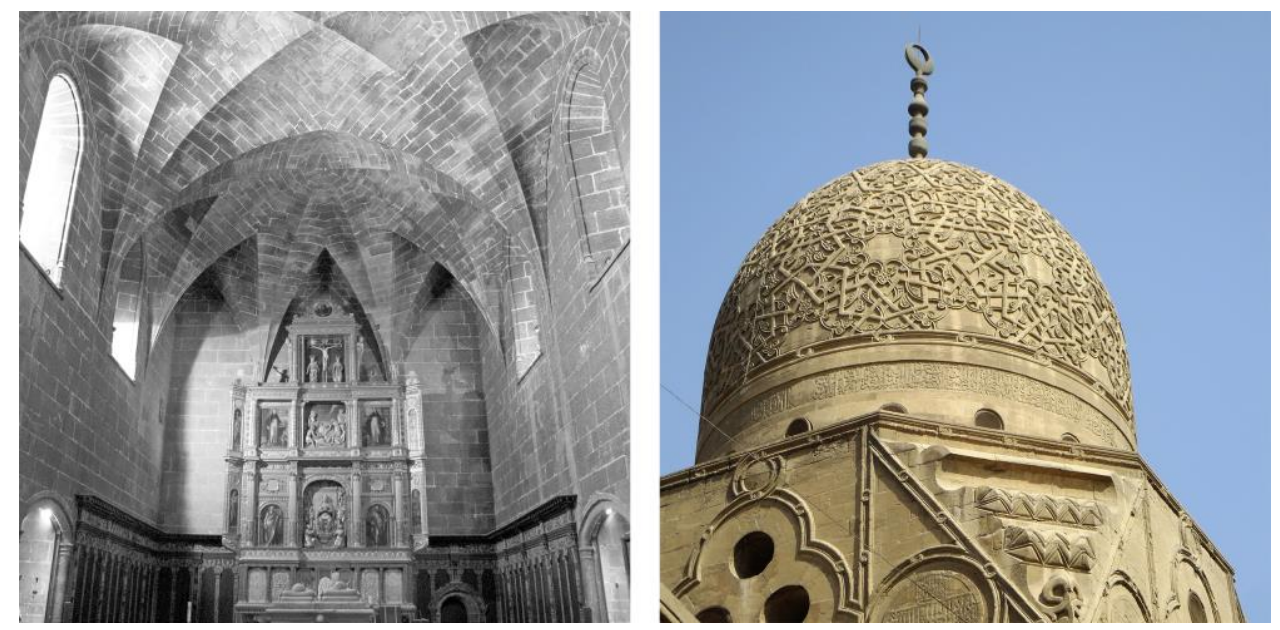

Fig. 20. Left: Francesc Baldomar and Pere Compte, star-shaped vault, Capilla de Los Reyes, 1437-57, Convent of Santo Domingo, Valencia. Right: Dome, funerary complex of Sultan al-Ashraf Qaytbay, Cairo, 1472-74.

\section{Bibliography}

Abulafia, David, The Great Sea: a Human History of the Mediterranean, New York: Oxford University Press, 2011.

Altshuler, Douglas L., William B. Dickson, Jason T. Vance, Stephen P. Roberts, and Michael H. Dickinson, 'Short-amplitude high-frequency wing strokes determine the aerodynamics of honeybee flight', PNAS 102, 50 (2005), pp. 18213-18218.

Anderson, Jaynie (ed.), Crossing Cultures: Conflict, Migration and Convergence, Carlton: Miegunyah Press, 2009.

Antista, Giuseppe and Maria Mercedes Bares, Le scale in pietra a vista nel Mediterraneo, Palermo: Caracol, 2013.

Bails, Benito, Elementos de matemática, Madrid: Joachin Ibarra, pp. 1779-1790.

Bares, Maria Mercedes, Il Castello Maniace di Siracusa: stereotomia e tecniche costruttive nell'architettura del Mediterraneo, Siracusa: Emanuele Romeo, 2011.

Bergamo, Francesco and Gabriella Liva, Stereotomia: dalla pietra al digitale, Venice: Cafoscarini, 2010. 
Bouleau, Christophe, 'Bâtir une coupole en pierre de taille', Annales Islamologiques 41 (2007), pp. 209-228.

Braudel, Fernand, La Méditerranée et le monde méditerranéen à l'époque de Philippe II, Paris: Colin, 1949.

Bucher, François. 'The Dresden sketchbook of vault projection', in György Rózsa (ed.), Évolution générale et développements régionaux en histoire de l'art: actes $d u 22^{e}$ congrès international d'histoire de l'art, Budapest 1969, 3 vols., Budapest: Akadémiai Kiadó, 1972, vol. 1, pp. 527-537; vol. 3, pp. 163-172.

California State University, Fresno, Index of Armenian Architecture, http://www.fresnostate.edu/artshum/armenianstudies/resources/indexarmenia narchitecture.html.

Calvo López, José, Cerramientos y trazas de montea de Ginés Martínez de Aranda, Ph.D. diss., Universidad Politécnica de Cartagena, 1999.

Chéreau, Jean, Traité d'architecture [1567-74], Biblioteka Publiczna, Gdanzk, ms. 2280.

Choisy, Auguste, Histoire de l'architecture, 2 vols, Paris: Gauthier-Villars, 1899.

Cipriani, Barbara, Development of Construction Techniques in the Mamluk Domes of Cairo, Master's thesis, Massachusetts Institute of Technology, 2005.

Cipriani, Barbara and Wanda W. Lau, 'Construction Techniques in Medieval Cairo: the Domes of Mamluk Mausolea (1250 A.D.-1517 A.D.)', in Malcolm Dunkeld (ed.), Proceedings of the Second International Congress on Construction History, Queen's College, Cambridge University 29 March-2 April 2006, Cambridge: Construction History Society, 2006, pp. 695-716.

Curabelle, Jacques, Examen des œuvres du Sr. Desargues, Paris: Henault, 1644.

D'Amato, Claudio and Giuseppe Fallacara, 'Tradizione e innovazione nella progettazione/costruzione dell'architettura: ruolo del 'modello' e attualità della stereotomia', in Id. (eds.), L'art de la stéréotomie/L'arte della stereotomia: Les compagnons du devoir et les merveilles de la construction en pierre/I compagnons du devoir e le meraviglie della costruzione in pietra, Paris: Librairie du compagnonnage, 2005, pp. 52-89.

De Angelis d'Ossat, Guglielmo, 'Le Origini romane della cupola bizantina', Rivista Romana 14 (1936), pp. 3-12.

De Angelis d'Ossat, Guglielmo, Romanità delle cupole paleocristiane, Rome: Reale Istituto di Studi Romani, 1946. 
Defilippis, Francesco, Architettura e stereotomia: caratteri dell'architettura in pietra da taglio in area mediterranea, Bari: Poliba, 2010.

Deplazes, Andrea and Christoph Wieser, 'Solid and filigree construction', in Andrea Deplazes (ed.), Constructing Architecture: Materials, Processes, Structures, Basel: Birkhäuser, 2005, pp. 13-15.

Desargues, Gérard, Brouillon projet d'exemple d'une manière universelle du S.G.D.L. touchant la praticque du trait à preuve pour la coupe des pierres en l'architecture, Paris, 1640.

Donabédian, Patrick, L'âge d'or de l'architecture arménienne: VII siècle, Marseille: Parenthèses, 2008.

Etlin, Richard A., Giuseppe Fallacara, and Luc Tamborero (eds.), Plaited Stereotomy: Stone Vaults for the Modern World, Rome: Aracne, 2008.

Fallacara, Giuseppe, Claudio D’Amato, Marco Stigliano and Richard A. Etlin (eds.), Stereotomy: Stone Architecture and New Research, Paris: Presses des Ponts, 2012.

Frézier, Amédée-François, La théorie et la pratique de la coupe des pierres et des bois, ou traité de stéréotomie à l'usage de l'architecture, 3. vols., Strasbourg: Dousseker, 1737-39.

Fundación Santa María La Real, Rómanico digital, http://www.romani codigital.com.

Gentillâtre, Jacques, Livre d'architecture [ca. 1615-25], Bibliothèque nationale de France, ms. fond français 14727.

Giovannoni, Gustavo, 'L'organismo a volta dall'architettura romana alla bizantina,' Felix Ravenna 27, 1 (1939), pp. 5-30.

Giovannoni, Gustavo, 'Volte romane e volte bizantine', in Atti del V Congresso Internazionale di Studi Bizantini: Roma 20-26 settembre 1936, 2 vols., Rome: Tipografie del Senato, 1940, vol. 2, pp. 133-138.

Grossman, Heather E. and Alicia Walker (eds.), Mechanisms of exchange: transmission in medieval art and architecture of the Mediterranean, ca. 1000-1500, Leiden: Brill, 2013.

Herráez Cubino, Guillermo, El léxico de los tratados de cortes de cantería españoles del siglo XVI, Ph.D. diss., Universidad de Salamanca, 2007.

Horden, Peregrine and Nicholas Purcell, The Corrupting Sea: A Study of Mediterranean History, Oxford: Blackwell, 2000.

Humboldt-Universität zu Berlin, Census of Antique Works of Art and Architecture Known in the Renaissance, http://www.census.de. 
Institut du monde arabe, Qantara: Mediterranean Heritage, http://www.qantaramed.org.

Janberg, Nicolas, Structurae: International Database for Civil and Structural Engineering, https://structurae.net.

Jouberton, Guy, Tracés et coupes des pierres, Dourdan: Vial, 2007.

Jousse, Mathurin, Le secret d'architecture découvrant fidèlement les traits géométriques, couppes, et derobemens nécessaires dans les bastiments enrichi d'un grand nombre de figures, adioustées sur châque discours pour l'explication d'iceux, La Flèche: George Griveau, 1642.

Kessler, Christel, The Carved Masonry Domes of Mediaeval Cairo, Cairo: American University in Cairo Press, 1976.

La maçonnerie et la taille de pierre, edited by Association ouvrière des Compagnons du devoir de France, Paris: Librairie du compagnonnage, 1991-2007.

L'Orme, Philibert de, Premier tome de l'architecture, Paris: Morel, 1567.

Magnan, Antoine, Le vol des insects, Paris: Hermann, 1934.

Maranci, Christina, Medieval Armenian Architecture: Constructions of Race and Nation, Leuven: Peeters, 2001.

Martínez de Aranda, Ginés and Antonio Bonet Correa (ed.), Cerramientos y trazas de montea [ca. 1600], Madrid: Servicio Histórico Militar, Comisión de Estudios Históricos de Obras Públicas y Urbanismo, 1986.

Massachusetts Institute of Technology and Aga Khan Trust for Culture, ArchNet, http://archnet.org.

Monge, Gaspard, Géométrie descriptive: leçons données aux Écoles normales l'an 3 de la République, Paris: Gabay, 1798.

Navarro Fajardo, Juan Carlos (ed.), Bóvedas valencianas: arquitecturas ideales, reales y virtuales en época medieval y moderna, Valencia: Editorial Universitat Politècnica de València, 2014.

Nobile, Marco Rosario (ed.), Matteo Carnilivari, Pere Compte: 1506-2006: due maestri del gotico nel Mediterraneo, Palermo: Caracol, 2006. Exhibition catalog.

Nobile, Marco Rosario (ed.), La stereotomia in Sicilia e nel Mediterraneo: guida al Museo di Palazzo La Rocca a Ragusa Ibla, Palermo: Caracol, 2013.

Nobile, Marco Rosario, 'Rinascimento alla francese: Gabriele Licciardo, architettura e costruzione nel Salento della metà del Cinquecento', Artigrama 30 (2015), pp. 193-219. 
Nussbaum, Norbert and Sabine Lepsky, Das gotische Gewölbe: eine Geschichte seiner Form und Konstruktion, München: Deutscher Kunstverlag, 1999.

O'Kane, Bernard, 'The Carved Stone Domes of Cairo', Paper presented at the conference 'Masons at Work', University of Pennsylvania, 30 March-1 April 2012, http://www.sas.upenn.edu/ancient/publications.html.

Palacios, José Carlos, Trazas y cortes de cantería en el Renacimiento español, Madrid: Instituto Juan de Herrera, 1990.

Pérouse de Montclos, Jean-Marie, L'architecture à la française: du milieu du XV à la fin du XVIII siècle, Paris: Picard, 1982. Revised $2^{\text {nd }}$ edition, Paris: Picard, 2013.

Potié, Philippe, Philibert de l'Orme, figures de la pensée constructive, Marseille: Parenthèses, 1996.

Potié, Philippe, 'Le tracé d'épure, des carnet médiévaux aux traités de stéréotomie,' in Jean-Philippe Garric, Valérie Nègre, and Alice Thomine-Berrada (eds.), La construction savante: les avatars de la littérature technique, Paris: Picard, 2008, pp. 149-160.

Princeton University, Index of Christian Art: Romanesque Database, https://ica.princeton.edu/romanesque/main.php.

Roldán Martín, Juan (ed.), El arte de la piedra: teoría y práctica de la cantería, Madrid: CEU Ediciones, 2009.

Sakarovitch, Joël, Épures d'architecture: de la coupe des pierres à la géométrie descriptive, XVI ${ }^{e}$-XIX ${ }^{e}$ siècles, Basel: Birkhäuser, 1998.

Sanabria, Sergio Luis, 'From Gothic to Renaissance Stereotomy: the Design Methods of Philibert de l'Orme and Alonso de Vandelvira', Technology and Culture 30, 2 (1989), pp. 266-299

Semper, Gottfried and Harry Francis Mallgrave (ed.), Style in the technical and tectonic arts, or, Practical aesthetics, Los Angeles: Getty Research Institute, 2004.

Sobrino González, Miguel, 'Barcelona: las razones de una catedral singular', Goya 307/308 (2005), pp. 197-214.

Strzygowski, Josef, Orient oder Rom: Beiträge zur Geschichte der Spätantiken und Frühchristlichen Kunst, Leipzig: J.C. Hinrichs'sche Buchhandlung, 1901.

Talaverano, Rafael Martín, Carmen Pérez de los Ríos, and Rosa Senent Domínguez, 'Late Gothic German Vault Design Methods and its Relationship with Spanish Ribbed Vaults', in Robert Carvais, André Guillerme, Valérie Nègre, and Joël Sakarovitch (eds.), Nuts \& Bolts of Construction History: Culture, Technology and 
Society: Proceedings of the Fourth International Congress on Construction History, Paris, 3-7 July 2012, Picard: Paris, 2012, pp. 83-90.

Università degli Studi di Palermo, Cosmed: dalla stereotomia ai criteri antisismici: crocevia di sperimentazioni progettuali. Sicilia e Mediterraneo (XII-XVIII secolo). http://www.cosmedweb.org/immagini.php.

Vandelvira, Alonso de and Geneviève Barbé-Coquelin de Lisle (ed.), El tratado de arquitectura de Alonso de Vandelvira [Libro de trazas de cortes de piedras, ca. 1585], 2 vols., Madrid: Confederación Española de Cajas de Ahorros, 1977.

Viollet-le-Duc, Eugène-Emmanuel, Dictionnaire raisonné de l'architecture française du $\mathrm{XI}^{e}$ au XVI ${ }^{e}$ siècle, 10 vols., Paris: B. Bance, 1854-1868.

Wahby, Ahmed and Dina Montasser, 'The Ornamented Domes of Cairo: The Mamluk Mason's Challenge', Paper presented at the conference Masons at Work, University of Pennsylvania, 30 March-1 April 2012, http://www.sas.upenn.edu Lancient/publications.html.

Zaragozá Catalán, Arturo, El arte de corte de piedras en la arquitectura valenciana del cuatrocientos: un estado de la cuestión, Valencia: Real Academia de Bellas Artes de San Carlos de Valencia, 2008.

Zaragozá Catalán, Arturo, José Calvo López, and Pau Natividad Vivó (eds.), 'Stereotomic Exchanges between Iberia and France in the $16^{\text {th }}$ century: Benoit Augier, Valencian Stairways and the Escalier de Toulouse', in Robert Carvais, André Guillerme, Valérie Nègre, and Joël Sakarovitch (eds.), Nuts \& Bolts of Construction History: Culture, Technology and Society: proceedings of the Fourth International Congress on Construction History, Paris, 3-7 July 2012, 3 vols., Paris: Picard, 2012, vol. 1, pp. 385-392.

Zaragozá Catalán, Arturo and Mercedes Gómez Ferrer, 'Costruyendo en la Valencia cuatrocentista: la fundación del gremio de canteros', in Id. (eds.), Pere Compte Arquitecto, Valencia: Ajuntament de Valencia, 2007, pp. 213-237.

Photo Credits

Fig. 1. Photo @ Sara Galletti.

Fig. 2. Photo (c) Romanceor (Own work) [GFDL (http://www.gnu.org Lcopyleft/fdl.html) or CC BY-SA 3.0 (https://creativecommons.org/licenses/by-

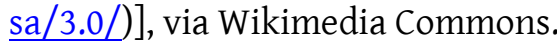


Fig. 3. Photo () Mbzt (Own work) [GFDL (http://www.gnu.org /copyleft/fdl.html) or CC BY 3.0 (http://creativecommons.org/licenses/by/3.0)], via Wikimedia Commons.

Fig. 4. Photos @ Sara Galletti.

Fig. 6. Drawing (C) Sara Galletti.

Fig. 7. Photo $\odot$ Simone Moni / GAR [CC BY-SA 4.0 (http://creativecommons.org/ licenses/by-sa/4.0)], via Wikimedia Commons.

Fig. 8. Photo $\odot$ François Walch, licensed by Francis Vérillon [GFDL (http://www .gnu.org/copyleft/fdl.html) or CC BY-SA 3.0 (http://creativecommons.org Llicenses/by-sa/3.0)] via Wikimedia Commons.

Fig. 9. Left: Photo (c) Manuel de Corselas (Own work) [CC BY-SA 3.0 (http://creativecommons.org/licenses/by-sa/3.0)], via Wikimedia Commons. Right: Photo (c) Daniel VILLAFRUELA [CC BY-SA 4.0 (http://creativecom mons.org/licenses/by-sa/4.0)], via Wikimedia Commons.

Fig. 10. Right: Photo (c) Hawobo [CC BY-SA 2.0 de (http://creativecom mons.org/licenses/by-sa/2.0/de/deed.en)], via Wikimedia Commons.

Fig. 11. (c) Sara Galletti.

Fig. 12. ( ) Sara Galletti.

Fig. 13. (c) Sara Galletti.

Fig. 14. Left: Photo (c) Associazione Culturale Cuore Sannita (http://www.cuoresannita.it). Right: Photos $\odot$ (above) Sailko (Own work) [CC BYSA $4.0 \quad$ (http://creativecommons.org/licenses/by-sa/4.0)], (below) Username.Ruge (Own work) [CC BY-SA 4.0 (http://creativecom mons.org/licenses/by-sa/4.0)], via Wikimedia Commons.

Fig. 15. Photos $($ Census of Antique Works of Art and Architecture Known in the Renaissance (http://www.census.de).

Fig. 16. Photo @ Ji-Elle (Own work) [Public domain], via Wikimedia Commons.

Fig. 17. @ Sara Galletti.

Fig. 18. Left: Photo (c) Mattis (Own work) [CC BY 2.0 (http://creativecommons .org/licenses/by/2.0)], via Wikimedia Commons. Right: Photo (c) Chatsam (Own work) [CC BY-SA 3.0 (http://creativecommons.org/licenses/by-sa/3.0)], via Wikimedia Commons. 
Fig. 20. Left: Photo (C) Felivet (Own work) [Public domain], via Wikimedia Commons. Right: Photo (c) Casual Builder (Own work) [CC BY-SA 3.0 (http://creativecommons.org/licenses/by-sa/3.0)], via Wikimedia Commons.

\section{Google Maps Photo Credits}

A Merca, Church of St Pedro da Mezquita, ( ) José Antonio Gil Martínez from Vigo, Spain (Iglesia de San Pedro da Mezquita Uploaded by tm) [CC BY 2.0 (http://creativecommons.org/licenses/by/2.0)], via Wikimedia Commons.

Afrin, Church of St. Simeon Stylite, 1 @ Bernard Gagnon (Own work) [GFDL (http://www.gnu.org/copyleft/fdl.html) or CC BY-SA 3.0 (http://creativecom mons.org/licenses/by-sa/3.0)], via Wikimedia Commons; 2 (c) Mappo (\{\{own\}\}) [GFDL (http://www.gnu.org/copyleft/fdl.html) or CC BY-SA 4.0-3.0-2.5-2.0-1.0 (http://creativecommons.org/licenses/by-sa/4.0-3.0-2.5-2.0-1.0)], via Wikimedia Commons; 3 (c) Graham van der Wielen (https://www.flickr.com/photos/ gray_um/2789891812/) [CC BY 2.0 (http://creativecommons.org/licenses /by/2.0)], via Wikimedia Commons.

Aiguilhe, Chapel of St Claire, (c) Torsade de Pointes (Own work) [Public domain], via Wikimedia Commons.

Akdamar Island, Church of the Holy Cross, (C) داود مجتهدى (Own work) [Public domain], via Wikimedia Commons.

Aleppo, Al-Firdaws Madrasa, (c) MIT OpenCourseWare [CC BY-SA 2.0 (https://creativecommons.org/licenses/by/2.0/)], via Flickr.

Aleppo, Bimaristan al-Arghuni, 1 (c) Bernard Gagnon (Own work) [GFDL (http://www.gnu.org/copyleft/fdl.html) or CC BY-SA 3.0 (http://creativecom mons.org/licenses/by-sa/3.0)], via Wikimedia Commons.

Almazán, Church of San Miguel, (c) Zarateman (Own work) [Cco], via Wikimedia Commons.

Ani (Ocakli), Cathedral, (c) Citrat from tr [GFDL (http://www.gnu.org /copyleft/fdl.html), or CC-BY-SA-3.0 (http://creativecommons.org/licenses/bysa/3.0/)], from Wikimedia Commons.

Anipemza, Yereruyk Basilica, (c) 23artashes (Own work) [CC BY-SA 3.0 (http://creativecommons.org/licenses/by-sa/3.0)], via Wikimedia Commons.

Apt, Cathedral, (c) Véronique PAGNIER (Own work) [GFDL (http://www.gnu.org/copyleft/fdl.html) or CC BY-SA 3.0 (http://creativecommons.org/licenses/by-sa/3.0)], via Wikimedia Commons. 
Arles, Roman amphitheater, (c) Carole Raddato from FRANKFURT, Germany (The Arles Amphitheatre, built in 90 AD, Arelate) [CC BY-SA 2.0 (http://creativecommons.org/licenses/by-sa/2.0)], via Wikimedia Commons.

Artik, Lmbat Monastery, Church of St Stephen (Lmbatavank), 1, 2, and 3 @ Arman musikyan (Own work) [CC BY-SA 4.0 (http://creativeCommons.org/licenses/bysa/4.0)], via Wikimedia Commons.

Aruch (Talich), Cathedral (Aruchavank), @ nina stoessinger (originally posted to Flickr as Empty) [CC BY-SA 2.0 (http://creativeCommons.org/licenses/bysa/2.0)], via Wikimedia Commons.

Ashtarak, Karmravor Church, (c) Bertramz (Own work) [CC BY-SA 3.0 (http://creativeCommons.org/licenses/by-sa/3.0)], via Wikimedia Commons.

Ashtarak, Tsiranavor Church, (c) Liveon001 (Own work) [CC BY-SA 3.0 (http://creativeCommons.org/licenses/by-sa/3.0) or GFDL (http://www.gnu. org/copyleft/fdl.html)], via Wikimedia Commons.

Avan (Yerevan), Katoghike Tsiranavor Church, @ Liveon001 @Travis Witt (Own work) [CC BY-SA 3.0 (http://creativeCommons.org/licenses/by-sa/3.0) or GFDL (http://www.gnu.org/copyleft/fdl.html)], via Wikimedia Commons.

Avignon, Pont Saint Bénézet, Chapel of St Nicolas, (c) François de Dijon (Own work) [CC BY-SA 3.0 (http://creativeCommons.org/licenses/by-sa/3.0)], via Wikimedia Commons.

Baalbek, Temple of Venus (c) Varun Shiv Kapur [CC BY-SA 2.0 (https://creativeCommons.org/licenses/by/2.0/)], via Flickr.

Boada de Villadiego, Church of Nuestra Señora de la Asunción, @ MottaW (Own work) [CC BY-SA 3.0 (http://creativeCommons.org/licenses/by-sa/3.0)], via Wikimedia Commons.

Cabria, Church of St Andrés, (c) Valdavia (Own work) [CC BY-SA 3.0 (http://creativeCommons.org/licenses/by-sa/3.0)], via Wikimedia Commons.

Cairo, Al Zahir Baybars Mosque, (c) Martyn Smith [CC BY 2.0 (http://creativeCommons.org/licenses/by/2.0)], via Wikimedia Commons.

Cairo, Complex of Sultan Qā'it Bay, (c) Casual Builder (Own work) [CC BY-SA 3.0 (http://creativeCommons.org/licenses/by-sa/3.0)], via Wikimedia Commons.

Cairo, Mausoleum of Qansuh Abu Sa'id, (c) Tekisch (Own work) [CC BY-SA 3.0 (http://creativeCommons.org/licenses/by-sa/3.0)], via Wikimedia Commons.

Cairo, Mosque of Sultan al-Muayyad, 1 @ Francisco Anzola (Al-Mu'ayyad) [CC BY 2.0 (http://creativeCommons.org/licenses/by/2.0)], via Wikimedia Commons; 2 
(C) Francesco Gasparetti from Senigallia, Italy (Cairo: moschea di el-Muhayyad) [CC BY 2.0 (http://creativeCommons.org/licenses/by/2.0)], via Wikimedia Commons.

Caserta Vecchia, Church of San Michele Arcangelo (Duomo), @ Velvet (Own work) [CC BY-SA 3.0 (http://creativeCommons.org/licenses/by-sa/3.0)], via Wikimedia Commons.

Castañeda, Colegiata de Santa Cruz, (c) GFreihalter (Own work) [CC BY-SA 3.0 (http://creativeCommons.org/licenses/by-sa/3.0)], via Wikimedia Commons.

Castillana del Mar, Collegiate Church of St Juliana, ( ) José Luis Filpo Cabana (Own work) [CC BY 3.0 (http://creativeCommons.org/licenses/by/3.0)], via Wikimedia Commons.

Chartres, Cathedral, Crypt of St Lubin, (c) Harmonia Amanda (Own work) [GFDL (http://www.gnu.org/copyleft/fdl.html) or CC BY-SA 3.0 (http://creative commons.org/licenses/by-sa/3.0)], via Wikimedia Commons.

Cherval, Church of St Martin, (c) Jack ma (Own work) [GFDL (http://www.gnu.org/copyleft/fdl.html) or CC BY-SA 3.0 (http://creativecommons.org/licenses/by-sa/3.0)], via Wikimedia Commons.

Cillamayor, Church of St María la Real, (c) GFreihalter (Own work) [CC BY-SA 3.0 (http://creativeCommons.org/licenses/by-sa/3.0)], via Wikimedia Commons.

Cruas, Church of Sainte Marie, (c) Rémi Mathis (Travail personnel) [GFDL (http://www.gnu.org/copyleft/fdl.html) ou CC BY-SA 3.0 (http://creativecommons.org/licenses/by-sa/3.0)], via Wikimedia Commons.

Cunault, Church of Notre Dame, (c) Jochen Jahnke at the German language Wikipedia [GFDL (http://www.gnu.org/copyleft/fdl.html) or CC-BY-SA-3.0 (http://creativeCommons.org/licenses/by-sa/3.0/)], via Wikimedia Commons.

Divriği, Ulu Mosque and Hospital, (c) Bertramz (Own work) [CC BY-SA 3.0 (http://creativeCommons.org/licenses/by-sa/3.0)], via Wikimedia Commons.

Dolianova, Cathedral, (c) Ettore (Own work) [CC BY-SA 3.0 (http://creativeCommons.org/licenses/by-sa/3.0/)], via Wikimedia Commons.

El Djem, Roman amphitheatre, (c) Vajta (Own work) [CC BY-SA 3.0 (http://creativeCommons.org/licenses/by-sa/3.0/)], via Wikimedia Commons.

Ferentino, Church of St Valentino, (c) A...periodico (Own work) [Public domain], via Wikimedia Commons. 
Fontdouce, Abbey, ( ) Jochen Jahnke at the German language Wikipedia [GFDL (http://www.gnu.org/copyleft/fdl.html) or CC-BY-SA-3.0 (http://creative Commons.org/licenses/by-sa/3.0/)], via Wikimedia Commons.

Fontevraud, Abbaye, 1 ( ) Nono vlf (Own work) [GFDL (http://www.gnu.org/copyleft/fdl.html) or CC BY-SA 3.0 (http://creative Commons.org/licenses/by-sa/3.0)], via Wikimedia Commons; 2 @ MOSSOT (Own work) [GFDL (http://www.gnu.org/copyleft/fdl.html) or CC BY-SA 3.0 (http://creativeCommons.org/licenses/by-sa/3.0)], via Wikimedia Commons.

Foz, Basilica of St Martin de Mondoñedo, (c) Marc [CC BY-SA 2.0 (https://creativeCommons.org/licenses/by/2.0/)], via Flickr

Friestas, Church of São Fins, (C) José Antonio Gil Martínez from Vigo, Spain (Iglesia de Sanfins de Friestas Uploaded by tm) [CC BY 2.0 (http://creativeCommons.org/licenses/by/2.0)], via Wikimedia Commons.

Frómista, Church of St Martín de Tours, (c) José Luis Filpo Cabana (Own work) [GFDL (http://www.gnu.org/copyleft/fdl.html) or CC BY 3.0 (http://creative Commons.org/licenses/by-sa/3.0/)], via Wikimedia Commons.

Gensac-la-Pallue, Church of St Martin, @) Jack ma (Own work) [GFDL (http://www.gnu.org/copyleft/fdl.html) or CC BY-SA 3.0 (http://creative Commons.org/licenses/by-sa/3.0/)], via Wikimedia Commons.

Gloucester, Cathedral, (c) Chris Gunns [CC BY-SA 2.0 (http://creative Commons.org/licenses/by-sa/2.0)], via Wikimedia Commons.

Irind, Church, (c) Bertramz (Own work) [CC BY-SA 3.0 (http://creative Commons.org/licenses/by-sa/3.0/)], via Wikimedia Commons.

Ispagnac, Church of St Pierre and St Paul, @ B BUFO8 (Own work) [CC BY-SA 3.0 (http://creativecommons.org/licenses/by-sa/3.0/)], via Wikimedia Commons.

Jerash, Roman nymphaeum, (c) Dennis Jarvis (https://www.flickr.com/ photos/archer10/2217593710/) [CC BY-SA $2.0 \quad$ (http://creative Commons.org/licenses/by-sa/2.0)], via Wikimedia Commons.

Jerusalem, Chapel of the Ascension, (c) Mattes (Own work) [Public domain], via Wikimedia Commons.

Jerusalem, Church of St Anne, (c) Berthold Werner (Own work) [Public domain], via Wikimedia Commons.

Kanlidivane, Basilica, (c) Ana al'ain (Own work) [CC BY-SA 4.0 (http://creativeCommons.org/licenses/by-sa/4.0)], via Wikimedia Commons. 
Khirbat al-Mafjar, Hisham's Palace, @ Deror_avi (Own work) [GFDL (http://www.gnu.org/copyleft/fdl.html) or CC BY-SA 3.0 (http://creative Commons.org/licenses/by-sa/3.0)], via Wikimedia Commons.

Kotyak, Geghard Monastery, (c) Shaun Dunphy (originally posted to Flickr as Geghard Monastery) [CC BY-SA 2.0 (http://creativeCommons.org/licenses/bysa/2.0)], via Wikimedia Commons.

La Garde-Adhémar, Church of St Michel, (C) Remi Mathis (Own work) [CC BY-SA 3.0 (http://creativeCommons.org/licenses/by-sa/3.0)], via Wikimedia Commons.

La Sauve, Sauve-Majeure Abbey, (c) Pinpin (Own work) [CC BY-SA 3.0 (http://creativeCommons.org/licenses/by-sa/3.0)], via Wikimedia Commons.

La Seu d'Urgell, Cathedral, (c) PMRMaeyaert (Own work) [CC BY-SA 3.0 (http://creativeCommons.org/licenses/by-sa/3.0)], via Wikimedia Commons.

Leptis Magna, market, (c) Franzfoto (Own work) [GFDL (http://www.gnu.org/copyleft/fdl.html) or CC BY-SA 3.0 (http://creativeCommons.org/licenses/by-sa/3.0)], via Wikimedia Commons.

Les Masies de Roda, Monastery of Sant Pere de Casserres, (c) PMRMaeyaert (Own work) [CC BY-SA 3.0 es (http://creativeCommons.org/licenses/bysa/3.0/es/deed.en)], via Wikimedia Commons.

Lucca, Basilica of St Frediano, (c) Joanbanjo (Own work) [CC BY-SA 3.0 (http://creativeCommons.org/licenses/by-sa/3.0)], via Wikimedia Commons.

Madenşehri (Binbirkilise), Church no. 1, (C) Jordan Pickett [CC BY-SA 2.0 (https://creativeCommons.org/licenses/by/2.0/)], via Flickr

Mainz, Cathedral, (c) Sabinolembo (Own work) [Public domain], via Wikimedia Commons.

Marmashen, Monastery, 1 (c) Arman musikyan (Own work) [CC BY-SA 3.0 (http://creativeCommons.org/licenses/by-sa/3.0)], via Wikimedia Commons; 2 (c) Marcin Konsek / Wikimedia Commons., via Wikimedia Commons.

Mastara, Church of St John, 1 @ Armen Manukov (Own work) [CC BY-SA 3.0 (http://creativeCommons.org/licenses/by-sa/3.0)], via Wikimedia Commons. 2 @ Lilitik22 (Own work) [CC BY-SA 4.0 (http://creativeCommons.org/licenses/bysa/4.0)], via Wikimedia Commons.

Mélas, Church of St Étienne, (c) MOSSOT (Own work) [CC BY-SA 4.0 (http://creativeCommons.org/licenses/by-sa/4.0)], via Wikimedia Commons.

Moirax, Church of Notre Dame, (c) Delatude (Own work) [CC BY-SA 4.0 (http://creativeCommons.org/licenses/by-sa/4.0)], via Wikimedia Commons. 
Monsempron-Libos, Church of St Géraud, ( $)$ MOSSOT (Own work) [CC BY-SA 4.0 (http://creativeCommons.org/licenses/by-sa/4.0)], via Wikimedia Commons.

Montmajour, Abbey of St. Peter, 1 @ SiefkinDR (Own work) [Public domain], via Wikimedia Commons; 2 (c) Finoskov (Own work) [CC BY-SA 3.0 (http://creativeCommons.org/licenses/by-sa/3.0)], via Wikimedia Commons.

Mushabbak, Basilica, (c) Varun Shiv Kapur (http://www.flickr. com/photos/varunshiv/5348855591/) [CC BY 2.0 (http://creativeCommons.org/ licenses/by/2.0)], via Wikimedia Commons.

Mut, Alahan Monastery, East Church, @ Nedim Ardoğa (My work) [CC BY-SA 3.0 (http://creativeCommons.org/licenses/by-sa/3.0/) or GFDL (http://www.gnu. org/copyleft/fdl.html)], via Wikimedia Commons.

Nant, Church of Saint Pierre, (c) Jacques MOSSOT (Own work) [CC BY-SA 4.0 (http://creativeCommons.org/licenses/by-sa/4.0)], via Wikimedia Commons.

Nasbinals, Church of St Marie, (c) BUFO88 (Own work) [CC BY-SA 4.0 (http://creativeCommons.org/licenses/by-sa/4.0)], via Wikimedia Commons.

Nîmes, Roman amphitheater, (c) Inkey (Own work) [CC BY-SA 3.0 (http://creativeCommons.org/licenses/by-sa/3.0)], via Wikimedia Commons.

Odzun, Church, (c) Arman musikyan (Own work) [CC BY-SA 3.0 (http://creativeCommons.org/licenses/by-sa/3.0)], via Wikimedia Commons.

Ottana, Church of St Nicola, (c) Gianni Careddu (Own work) [CC BY-SA 3.0 (http://creativeCommons.org/licenses/by-sa/3.0)], via Wikimedia Commons.

Oxford, Divinity School Library, (c) Diliff (Own work) [CC BY-SA 3.0 (http://creativeCommons.org/licenses/by-sa/3.0) or GFDL (http://www.gnu.org /copyleft/fdl.html)], via Wikimedia Commons.

Palencia, Cathedral, (c) Rowanwindwhistler (Own work) [CC BY-SA 3.0 (http://creativeCommons.org/licenses/by-sa/3.0/)], via Wikimedia Commons.

Palermo, Church of St Cataldo, (c) Jean-Pierre Dalbéra [CC BY 2.0 (http://creativeCommons.org/licenses/by/2.0)], via Wikimedia Commons.

Paris, Hôtel de Cluny, (c) Traumrune / Wikimedia Commons., via Wikimedia Commons.

Pemzashen, Church, 1 @ Soghomon Matevosyan (Own work) [CC BY-SA 4.0 (http://creativeCommons.org/licenses/by-sa/4.0)], via Wikimedia Commons; 2 ( Vahag851 (Own work) [CC BY-SA 3.0 (http://creativeCommons.org/licenses/bysa/3.0/)], via Wikimedia Commons. 
Ptghni, Church (Ptghnavank), (c) Vahagn Grigoryan (Own work) [CC BY-SA 3.0 (http://creativeCommons.org/licenses/by-sa/3.0)], via Wikimedia Commons.

Pula, Roman amphitheater, (c) Carole Raddato from FRANKFURT, Germany [CC BY-SA 2.0 (http://creativeCommons.org/licenses/by-sa/2.0)], via Wikimedia Commons.

Qalb Lozeh, Basilica, (c) Simone Moni / GAR [CC BY-SA 4.0 (http://creativeCommons.org/licenses/by-sa/4.0)], via Wikimedia Commons.

Qasr al-Hallabat, Hammam As-Sarah, 1, 3 @ Erics (Own work) [CC BY-SA 4.0 (http://creativeCommons.org/licenses/by-sa/4.0)], via Wikimedia Commons; 2 @ TheLastShot (Own work) [Public domain], via Wikimedia Commons.

Rabós, Monastery of St Quirze de Colera, ( ) EnfoEnfo (Own workOwn work) [CC BY-SA 4.0 (http://creativeCommons.org/licenses/by-sa/4.0) or CC BY-SA 3.0 (http://creativeCommons.org/licenses/by-sa/3.0/)], via Wikimedia Commons.

Ravenna, Mausoleum of Theodoric, (c) Sailko (Own work) [CC BY-SA 4.0 (http://creativeCommons.org/licenses/by-sa/4.0)], via Wikimedia Commons.

Resafa (Sergiopolis), Tetraconch, (c) Marina Milella / DecArch [CC BY-SA 4.0 (http://creativeCommons.org/licenses/by-sa/4.0)], via Wikimedia Commons.

Rome, Arch of Dolabella, (c) LPLT (Own work) [CC BY-SA 3.0 (http://creative Commons.org/licenses/by-sa/3.0/) or GFDL (http://www.gnu.org/copyleft [fdl.html)], via Wikimedia Commons.

Rome, Arco dei Pantani. Public domain (https://Commons.wikimedia.org Lw/index.php?curid=965216)

Rome, Colosseum, (c) Diana Ringo (Own work) [CC BY-SA 3.0 (http://creativeCommons.org/licenses/by-sa/3.0)], via Wikimedia Commons.

Sacramenia, Church of St Miguel, (c) Rowanwindwhistler (Own work) [GFDL (http://www.gnu.org/copyleft/fdl.html) or CC BY-SA 3.0 (http://creative Commons.org/licenses/by-sa/3.0/)], via Wikimedia Commons.

Safita, Chastel Blanc, Church of St Michael, (c) Yuber [Public domain], via Wikimedia Commons.

Saint-Amand-de-Coly, Abbey church, ( J Jochen Jahnke at the German language Wikipedia [GFDL (http://www.gnu.org/copyleft/fdl.html) or CC-BY-SA-3.0 (http://creativeCommons.org/licenses/by-sa/3.0/)], via Wikimedia Commons.

Saint-Gilles-du-Gard, Abbey of St Gilles, 1 @ Morburre (Own work) [CC BY-SA 3.0 (http://creativeCommons.org/licenses/by-sa/3.0/)], via Wikimedia Commons; 2 (c) Hawobo at German Wikipedia [CC BY-SA 2.0 de (http://creative 
Commons.org/licenses/by-sa/2.0/de/deed.en)], via Wikimedia Commons; 3 (c) rabbitslim (Own work) [GFDL (http://www.gnu.org/copyleft/fdl.html)], via Wikimedia Commons.

Saint-Thierry, Church of St Hilaire, (c) Peter Potrowl (Own work) [CC BY-SA 4.0 (http://creativeCommons.org/licenses/by-sa/4.0)], via Wikimedia Commons.

Saint-Trinit, Church of St Trinité, ( ) Véronique PAGNIER (Own work) [CCo], via Wikimedia Commons.

Salamanca, Church of St Marcos, (c Diocese of Westminster (Flickr: DSC_0878) [CC BY 2.0 (http://creativeCommons.org/licenses/by/2.0)], via Wikimedia Commons.

Salona, Roman Amphitheatre, (c) Carole Raddato from FRANKFURT, Germany (Amphitheatre, Salona, Dalamatia) [CC BY-SA 2.0 (http://creative Commons.org/licenses/by-sa/2.0)], via Wikimedia Commons.

San Donato in Poggio, Church of St Donato, (c) Vignaccia76 (Own work) [CC BY 3.0 (http://creativeCommons.org/licenses/by/3.0)], via Wikimedia Commons.

San Leo (Rimini), Pieve di Santa Maria Assunta, (c Il Faentino (Own work) [Public domain], via Wikimedia Commons.

San Martín de Montalbán, Church of Santa María de Melque, ( ) José Luis Filpo Cabana (Own work) [GFDL (http://www.gnu.org/copyleft/fdl.html) or CC BY 4.0 (http://creativeCommons.org/licenses/by/4.0)], via Wikimedia Commons.

Sant Martí Sarroca, Church of St Maria, ( ) Angela Llop from Spain (Santa Maria de Sant Martí Sarroca.) [CC BY-SA 2.0 (http://creativeCommons.org/licenses/by$\mathrm{sa} / 2.0)$ ], via Wikimedia Commons.

Sant'Antioco di Bisarcio, Cathedral, 1 @ Gianni Careddu (Own work) [CC BY-SA 3.0 (http://creativeCommons.org/licenses/by-sa/3.0/)], via Wikimedia Commons; 2 (c) Sailko (Own work) [CC BY 3.0 (http://creativeCommons.org/licenses/by/3.0)], via Wikimedia Commons.

Santa María de Mave, Monastery of St María la Real, ( ) Valdavia (Own work) [GFDL (http://www.gnu.org/copyleft/fdl.html) or CC BY-SA 4.0-3.0-2.5-2.0-1.0 (http://creativeCommons.org/licenses/by-sa/4.0-3.0-2.5-2.0-1.0)], via Wikimedia Commons.

Segovia, Church of St Millán, (c) Juan Carlos Castle (Own work) [CC BY-SA 3.0 es (http://creativeCommons.org/licenses/by-sa/3.0/es/deed.en)], via Wikimedia Commons.

Shivta, Church, (c) Ester Inbar, available from http://Commons. wikimedia.org/wiki/User:ST. [Attribution], via Wikimedia Commons. 
Siracusa, Castello Maniace, (c) I, Sailko [GFDL (http://www.gnu.org/ copyleft/fdl.html), CC-BY-SA-3.0 (http://creativeCommons.org/licenses/by-

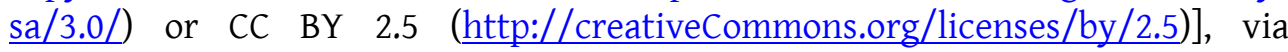
Wikimedia Commons.

Sisian, Church of St John, (c) Soghomon Matevosyan (Own work) [CC BY-SA 4.0 (http://creativeCommons.org/licenses/by-sa/4.0)], via Wikimedia Commons.

Soria, Church of St Juan de Rabanera, ( ) José Luis Filpo Cabana (Own work) [GFDL (http://www.gnu.org/copyleft/fdl.html) or CC BY 4.0 (http://creative Commons.org/licenses/by/4.0)], via Wikimedia Commons.

Soria, Monastery of St Juan de Duero, (c) Miguel Ángel García. from Ólvega., España (Iglesia de San Juan de Duero.Soria.) [CC BY 2.0 (http://creative Commons.org/licenses/by/2.0)], via Wikimedia Commons.

Sousse, Great Mosque, Public domain, https://en.wikipedia.org/wiki/File: Great_Mosque_of_Sousse,_Tunisia.jpg.

Sultanhanı, Sultan Han Caravanserai, (c) Claude Valette (Own work) [GFDL (http://www.gnu.org/copyleft/fdl.html).

Talin, Cathedral, (c) Arman musikyan (Own work) [CC BY-SA 4.0 (http://creativeCommons.org/licenses/by-sa/4.0)], via Wikimedia Commons.

Talin, Church of St Astvatsatsin, (C) nina stoessinger (originally posted to Flickr as weathered) [CC BY-SA 2.0 (http://creativeCommons.org/licenses/by-sa/2.0)], via Wikimedia Commons.

Tartus, Cathedral, ( ) Library of Congress (Library of Congress) [Public domain], via Wikimedia Commons.

Tripoli, Taynal mosque, (c) Wilmerdon (Own work) [CC BY-SA 4.0 (http://creativeCommons.org/licenses/by-sa/4.0)], via Wikimedia Commons.

Tsitsernavank, Monastery church, 1 ○ lori-m.Lori-m at ru.wikipedia [Public domain], from Wikimedia Commons; 2 @ Soghomon Matevosyan (Own work) [CC BY-SA 4.0 (http://creativeCommons.org/licenses/by-sa/4.0)], via Wikimedia Commons.

Uta, Church of St Maria, (c) Giova81 (Own work) [GFDL (http://www.gnu.org/copyleft/fdl.html) or CC-BY-SA-3.0 (http://creative commons.org/licenses/by-sa/3.0/)], via Wikimedia Commons.

Vagharshapat, Church of St Hripsime, (c) Arman musikyan (Own work) [CC BY-SA 3.0 (http://creativeCommons.org/licenses/by-sa/3.0)], via Wikimedia Commons. 
Valencia, Cathedral, 1 ○ Joanbanjo (Own work) [Public domain], via Wikimedia Commons; 2 (c) Miguel Hermoso Cuesta (Own work) [CC BY-SA 4,0 (http://creativeCommons.org/licenses/by-sa/4.0)], via Wikimedia Commons.

Valencia, Church of St Nicolás de Bari and St Pedro Mártir, @ Joanbanjo (Own work) [Public domain], via Wikimedia Commons.

Valencia, Convent of St Domingo, (c) Felivet (Own work) [Public domain], via Wikimedia Commons.

Valencia, Palacio de la Generalitat, ( ) Joanbanjo (Own work) [Public domain], via Wikimedia Commons.

Valencia, Palacio de Mercaders, (c) Joanbanjo (Own work) [Public domain], via Wikimedia Commons.

Valencia, Real Monasterio de la Trinidad, ( Joanbanjo (Own work) [CC BY-SA 3.0 (http://creativeCommons.org/licenses/by-sa/3.0)], via Wikimedia Commons.

Valencia, Torres de Quart, (c) Jaume Meneses (Flickr: País Valencià'2011) [CC BYSA 2.0 (http://creativeCommons.org/licenses/by-sa/2.0)], via Wikimedia Commons.

Verona, Roman Amphitheatre, (c) Lo Scaligero (Own work) [CC BY-SA 3.0 (http://creativeCommons.org/licenses/by-sa/3.0)], via Wikimedia Commons.

Veyrines, Church of Notre Dame, (C) François Bassaget (Own work) [CC BY-SA 4.0 (http://creativeCommons.org/licenses/by-sa/4.0)], via Wikimedia Commons.

Vilanova de Dozón, Church of St Pedro, (c) P.Lameiro (Own work) [CC BY-SA 3.0 (http://creativeCommons.org/licenses/by-sa/3.0)], via Wikimedia Commons.

Worms, Cathedral, (c) HOWI - Horsch, Willy (Own work) [CC BY-SA 3.0 (http://creativeCommons.org/licenses/by-sa/3.0)], via Wikimedia Commons.

Zamora, Church of St María Magdalena, (c) Jose Luis Filpo Cabana (Own work) [GFDL (http://www.gnu.org/copyleft/fdl.html) or CC BY 3.0 (http://creative commons.org/licenses/by/3.0)], via Wikimedia Commons.

Zamora, Church of St Pedro y Ildefonso, (C) Jose Luis Filpo Cabana (Own work) [GFDL (http://www.gnu.org/copyleft/fdl.html) or CC BY 3.0 (http://creative commons.org/licenses/by/3.0)], via Wikimedia Commons.

Zoravan, Zoravor Church (Gharghavank), 1 @ Armen Manukov (Own work) [CC BY-SA 3.0 (http://creativeCommons.org/licenses/by-sa/3.0)], via Wikimedia Commons; 2 (c) Liveon001 (Own work) [CC BY-SA 3.0 (http://creative Commons.org/licenses/by-sa/3.0) or GFDL (http://creativeCommons. org/licenses/by-sa/3.0/)], via Wikimedia Commons. 
Zorita del Páramo, Church of St Lorenzo, ( ) Gesu (Own work by Gesu) [GFDL (http://www.gnu.org/copyleft/fdl.html) or CC BY 3.0 http://creativeCommons. org/licenses/by-sa/3.0/)], via Wikimedia Commons.

Zovuni, St. Peter and Paul, @ Zgalstyan (Own work) [CC BY-SA 3.0 (http://creative Commons.org/licenses/by-sa/3.0/)], via Wikimedia Commons. 